AperTO - Archivio Istituzionale Open Access dell'Università di Torino

\title{
CIRSE Guidelines on Percutaneous Needle Biopsy (PNB)
}

\section{This is the author's manuscript}

Original Citation:

Availability:

This version is available http://hdl.handle.net/2318/1640921

since 2018-07-06T21:22:39Z

Published version:

DOI:10.1007/s00270-017-1658-5

Terms of use:

Open Access

Anyone can freely access the full text of works made available as "Open Access". Works made available under a Creative Commons license can be used according to the terms and conditions of said license. Use of all other works requires consent of the right holder (author or publisher) if not exempted from copyright protection by the applicable law. 


\section{CardioVascular and Interventional Radiology CIRSE Guidelines on Percutaneous Needle Biopsy (PNB) \\ --Manuscript Draft--}

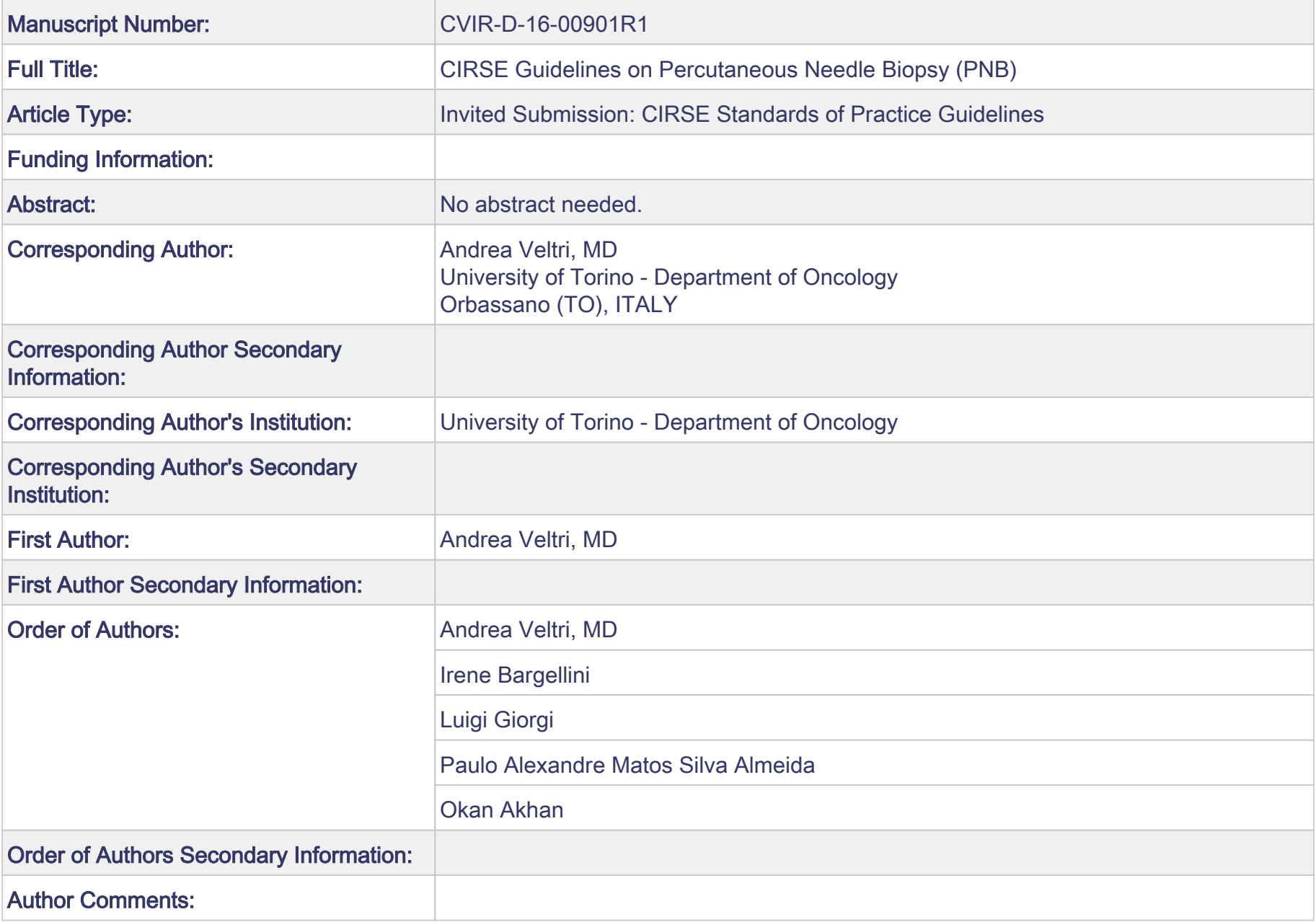




\section{CIRSE Guidelines on Percutaneous Needle Biopsy (PNB)}

\section{Introduction}

Image-guided Percutaneous Needle Biopsy (PNB) has proven to be a safe and effective procedure, and it became a common procedure representing an essential step for diagnosis and treatment planning in many situations.

Compared to open or excisional biopsy, image-guided percutaneous biopsy is less invasive and can be proposed as an outpatient service in the majority of cases.

However, success of PNB is strictly related to proper patient selection, preparation and postprocedural management as well as adequate procedural planning and monitoring.

Moreover, in the era of personalized cancer therapy, role of PNB is evolving since biomarker status today is guiding therapeutic decisions in many solid tumours, not only at initial diagnosis but also at the time of progression. Biological specimens are also becoming mandatory in many clinical trials. This new role of PNB implies a more intense involvement of interventional radiologists (IRs) in multidisciplinary discussions and clinical trial design, and it involves a deeper knowledge of molecular testing requirements, with concurrent development of new imaging guidance tools for the identification and localization of the most adequate target [1].

This document reviews current literature and provides Standards of Practice for imageguided PNB in different organs, with the exception of breast biopsy whose peculiar features deserve a separate dissertation.

\section{Definitions}

PNB is defined as insertion of a needle into a suspected lesion or an organ for the purpose of obtaining tissue or cells for diagnosis. The procedure is performed under guidance of imaging techniques such as Ultrasound (US), fluoroscopy, Computed Tomography (CT) or Magnetic Resonance Imaging (MRI), Cone Bean CT (CBCT) and Positron Emission Tomography CT (PET-CT). The imaging technique adopted depends on the lesion type and location, patients' compliance, technique availability and operators' preferences. PNB includes fine needle aspiration biopsy (FNAB) and core biopsy (CB). FNAB is the use of a thin, hollow needle (18-25 gauge) able to extract cells for cytological evaluation by aspiration and in some cases small tissue pieces for histological examination. $C B$ is the use of a hollow 
needle (9-20 gauge) [2] with a cutting and/or capturing mechanism that allows the extraction of a piece of tissue for histological evaluation.

Technical success of PNB is defined as the procurement of sufficient material to establish a diagnosis and/or guide treatment decisions.

Clinical success of PNB is defined as the outcome of patients depending on the results of biopsy, in term of appropriateness of medical or surgical management according to specific guidelines (e.g., selection for oncologic targeted therapies, active surveillance as an alternative to invasive treatment).

Complications are stratified on the basis of their outcome (see, Appendix A)[3]. Major complications result in hospital admittance (for outpatient procedures) or prolonged hospitalization (for in-patient procedures), unplanned increase in level of cares, permanent sequelae or death. Minor complications result in no sequelae; they may require therapy or a short (generally overnight) hospital stay [3].

\section{Pre-procedural imaging evaluation}

The vast majority of cases who are referred to PNB have undergone at least one preprocedural cross-sectional and/or functional study, including US, CT, MR or Positron Emission Tomography-CT (PET-CT), depending on the clinical issue. Careful review of the images by an IR is mandatory for the success of a PNB [4]. Indication to PNB should be discussed with the referring physicians, including the type of biopsy (core-biopsy for histology versus FNAB for cytology), taking into account the clinical needs and the procedural risks. In particular cases, indications to biopsy and/or alternative ways to obtain a diagnostic specimen may be discussed within Multidisciplinary Boards. It is essential to confirm the indications for PNB, to identify the optimal target and to question the differential diagnoses, thus helping the subsequent pathological assessment. Pre-procedural images allow procedural planning, including the selection of the most proper imaging guidance (with or without contrast injection to better detect the lesion), patient's position, access routes, needle type and trajectory, scheduled number of samples. Finally, imaging may enable the identification of potential contraindications and risks of PNB, anticipating possible complications (for instance, when the target lesion is adjacent to organs at risk for bleeding). 
A written report of the pre-procedural evaluation is suggested as a part of the PNB procedure.

\section{Indications and contraindications to PNB}

Indications for PNB include, but are not limited to, the following:

- To establish the nature of diffuse parenchymal disease;

- To obtain material for microbiological analyses in suspected or known infections;

- To establish the benign or malignant nature of a suspected tumour;

- To classify a malignancy (including immunohistochemistry-IHC evaluation);

- To stage a patient with known (or suspected) malignant tumours elsewhere;

- To obtain material for molecular analysis.

Image-guided PNB is a relatively non-invasive procedure, thus the absolute contraindications are rare and include:

- Lack of a safe access;

- Non-correctable coagulopathy;

- Refusal of consent.

The relative contraindications include all those conditions that increase the risk of complications. They should be promptly recognized and, when possible, corrected. They include:

- Coagulopathies;

- Inability of patient to cooperate (general anaesthesia may be considered);

- Significant comorbidities (i.e., hemodynamic or respiratory instability);

- Pregnancy (mainly if ionizing radiation exposure is required).

\section{Patient Preparation}

Patient clinical assessment and preparation is critical for a success of PNB. Before the procedure, special attention should be paid to the review of relevant medical history, medications and laboratory data [5].

Baseline vitals should be monitored before and during the procedure, particularly in moderate and high-risk biopsies. 
The evaluation of coagulation status is essential. When possible, antiplatelet/anticoagulation medications should be discontinued before the procedure, in particular for biopsies with moderate or significant risk of bleeding. When a cessation is problematic, risks and benefits should be carefully evaluated [6], and patients should be informed of potentially increased risk of bleeding. Recommendations for bleeding risk evaluation and management in PNB according to the Society of Interventional Radiology (SIR) and the Guidelines of the Cardiovascular and Interventional Radiological Society of Europe (CIRSE) [7] are summarized in Table 1.

Over the last years, new oral anticoagulants (NOACs) have become widely available. They are divided in two classes: oral direct thrombin inhibitors and oral direct factor Xa inhibitors. The main advantage of NOACs is the predictable anticoagulant effect at fixed doses without a need of routine monitoring. However, they lack of a reliable method to monitor anticoagulant activity and of an effective antidote. Management of NOACs before biopsy should be individualized based on drug type, procedure type, patient's clinical conditions and renal function. In general, NOACs should be withheld for 1-2 days before moderate and high-risk biopsies, and re-started 24 hours after the procedure (Table 1) [8].

\section{Informed consent}

Informed consent should be obtained directly from the operator who will carry out the procedure, following national laws and Institutional forms. The patients must be fully informed of the indications and benefits as well as of the risks and adverse events. Alternative options, when available, should be discussed. Finally, the procedure must be described thoroughly, including the need for peri-procedural medications, such as anaesthetics [4]. Whenever possible, the operator should meet the patient in advance. A written consent must be obtained in all moderate and high risk PNB, preferably 24 hours prior the procedure.

\section{Periprocedural medications}

A peripheral venous access (18-20 Gauge) should be obtained before the procedure, to ensure an immediate intravenous access in case medications or transfusions are required [5], except for very superficial biopsies (e.g. thyroid FNAB), depending on the operator's preference. 
Patients should be fasting for 4-6 $\mathrm{h}$ prior to the procedure, in particular when sedation is needed.

The need for sedation should be carefully evaluated. Sedation should be considered to increase patient's comfort and safety, on the basis of lesion location, procedure complexity, patient's compliance and comorbidities. General anaesthesia is recommended for children and for totally non-collaborating patients. While light sedation or anxiolysis can be managed safely by IRs and trained nursing staff, the administration of drugs for moderate and deep sedation should be reserved to personnel with knowledge and experience according to national legal regulations [9], such as anaesthesiologists or, on the basis of local policies, by IRs with appropriate training and certification.

Prophylactic antibiotics are not routinely administered for PNB, since the risk of contamination is low when the procedure is performed under sterile conditions. However, antibiotic prophylaxis can be indicated in immunocompromise patients and when targeting any potentially infected lesion or transgressing non-sterile anatomical structures (e.g. transcolic biopsies). There is no specific indication on type of antibiotic and there is no clear demonstration of superiority of long-course ( 3 days) over short-course ( 1 day) treatments, or that the use of multiple drugs may be superior to the single-drug regimen [10]. Recent studies have supported the role of targeted antibiotic prophylaxis selected on the basis of rectal cultures obtained before transrectal biopsy, to reduce the incidence of infections [11]. Generally, prophylaxis should start before the procedure.

\section{Patient positioning}

Patient is positioned according to the selected image-guided modality and access route, in a comfortable and stable position.

Patient positioning can be extremely useful in difficult procedures to move mobile structures away from the target and the biopsy tract. Moreover, patient stability might be particularly relevant when a navigation system is adopted.

Patients with respiratory compromise and severely obese patients should be evaluated carefully when a prone position is selected since they may experience breathing difficulties. When position implies the patient's visualization of the needle insertion (for instance, chest biopsies in supine position), more effort should be made in carefully describing all the 
manoeuvres to the patient before the procedure, to reduce anxiety and patient's movements.

\section{Imaging localization of the access site}

Once the patient is correctly positioned, the lesion and access route must be fully visualized by the selected imaging guidance [12].

Selection of an access route is critical to ensure success of PNB. Generally, the route should be as short as possible and should avoid all risky structures (lung fissures and bullae, large vessels, neural structures, biliary tree, bowel, renal sinus, etc.). In specific situations, a longer route is recommended; in subcapsular liver lesions, a longer tract with intervening normal liver parenchyma reduces the risk of hemoperitoneum; accordingly, in subpleural lesions, a longer oblique intraparenchymal needle path may facilitate the manoeuvre and increase technical success [13].

The site of skin puncture is marked and the distance from the skin puncture site to the target is measured to select the correct needle length. Under CT and MR guidance, the angle of access route can be measured, to guide needle insertion.

In specific situations, intra-venous contrast media injection (including contrast-enhanced US, e.g. for isoechoic liver or renal tumours) is required to visualize the lesion or the surrounding structures before PNB [14]. If the use of iodinated contrast media during the procedure is foreseen, pre-procedural evaluation of renal function is essential and the risk for contrastinduced nephropathy and allergy should be assessed, together with a potential need for prophylactic medication [5].

Respiratory motions must be taken into consideration when planning the access route, and patients should be instructed according to the operator's needs. In general, the lesions should be localized during the normal breathing to reduce the variability of deep breathholds.

\section{Skin disinfection and local anaesthesia}

Sterility is of paramount importance to avoid infectious complications. Once the access site is identified, the skin is cleaned and carefully sterilized using the standard technique $[9,12]$. The boundaries of the skin preparation should be wide enough to allow for possible adjustment of the entry site. The area around the access site is covered with sterile drapes. 
Local anaesthetic (usually $10-20 \mathrm{~mL}$ of lidocaine $1-2 \%$ ) is injected along the planned needle path. In case of a larger needle size (or coaxial introducer), a few millimetres skin incision is made using a scalpel blade.

Attention has to be paid to the operator's sterility as well (hygienic hand wash, decontaminated or disposable gown and sterile gloves) and the equipment decontamination, particularly in case of the US guidance (use of disposable transducer covers and sterile ultrasound gel) [9]. Whenever available, the biopsy instruments should be disposable, single-use items; otherwise, they should be submitted to machine decontamination and sterilization.

\section{Equipment Specifications}

\section{1) Staffing issues}

All procedures must be performed by a qualified IR physician with documented knowledge of risks and benefits of the procedure, imaging anatomy, imaging and monitoring equipment and radiation safety [15]. IR should have access to all required supplies and personnel to safely perform the procedure and ensure prompt treatment of complications [16]. The team performing the procedure should also include trained nursing staff and radiologic technologists [15]. When required, anaesthesiologists should be in charge of sedation [15]. In any case, emergency access to qualified acute care support should be guaranteed [16]. Success of PNB is finally ensured by the presence of qualified pathologists, adequately informed of PNB indications and relevant medical history. Onsite cytopathologic evaluation of fine-needle aspirations or touch preparations of core samples has the potential to improve PNB diagnostic yield [17].

\section{2) Image guidance}

PNB can be performed under US, CT, fluoroscopy, MR, Fluoro-CT, Cone-Beam CT or PET-CT guidance. Advantages and disadvantages of the most frequently used image guidance techniques are summarized in Table 2.

The selected imaging modality should allow:

- Complete visualization of all relevant anatomy;

- Sufficient visualization of equipment utilized during the procedure;

- Comfortable patient positioning and operator's manoeuvres; 
- Adequate evaluation and management of possible complications (e.g. pneumothorax);

- Limited ionizing radiation exposure (particularly in children and young patients).

To facilitate needle insertion and target visualization during PNB in difficult lesions, new software have become available that allow fusing images obtained from different modalities, such as CT, MR or PET-CT with real-time US or fluoroscopy [1,18-20]. Also, optical or electromagnetic navigation systems can be available in some facilities. These systems are able to fuse two or more imaging datasets in real-time (registration) and display the needle position on the real-time imaging dataset (tracking) by using electromagnetic or optical sensors placed on patient and on needle shaft [1,18-20].

\section{3) Facility}

Besides adequate equipment for image guidance, the facility in which PNB is performed must provide [16]:

- An area for patient preparation and post-procedural monitoring. This area can be located in the radiology department or in a short-stay unit, with immediate access to personnel and equipment to identify and treat possible complications. The vast majority of PNB are performed as outpatient procedures. However, before the procedure, hospitalization should be considered in fragile patients or when the risk of complications is deemed to be substantially higher.

- Access to emergency resuscitation equipment. The facility should provide appropriate equipment for the monitoring of heart rate, cardiac rhythm and blood pressure, an access to emergency resuscitation equipment and drugs, in order to be ready for any possible acute complication $[15,16]$. In case of thoracic PNB, aspirator to clear upper airways and equipment for decompression of tension pneumothorax (PNX) must be available. Physicians and nursing staff must be properly trained for the use of this equipment $[15,16]$. Equipment and medications should be monitored and inventoried on a regular basis.

- Access to laboratory facilities for tissue samples analysis. Success of PNB strongly depends on adequate specimen collection and expertise of the local pathologists. Specimen collection and preparation must be appropriate for the clinical question and should be sent to the biopsy facility together with all relevant medical history, to guide microbiological or pathological analysis. Consultation with local laboratory prior to the procedure may be 
useful in selected cases. Onsite cytopathology assessment is desirable to determine adequacy of sample [17].

\section{4) Procedure}

Before the procedure, IRs must check the availability of all required devices [15].

\section{Biopsy needles}

- FNAB needle: thin, hollow needle, 18-25G, able to extract cells for cytological evaluation by aspiration. The most commonly used are the spinal needles and the Chiba needles; when compared with Chiba needles, spinal needles have a thicker wall and smaller lumen, which makes their control somewhat easier. Other FNAB needles have been designed, and they mainly differ for the shape and cutting capabilities of the tip (Westcott, Franseen, Greene, Madayag, Turner needles).

- Tru-Cut needles: hollow needles, 9-20G, for CB, with a cutting mechanism that extract tissue sufficient for histologic analysis; the shape of cores is half-cylindrical and the capture mechanism changes according to the manufacturer and can be partially of fully automatic. Also, how far the cutting needle is advanced, when fired, changes according to the manufacturer and should be taken into consideration when planning the biopsy.

- Full-core needles: for $\mathrm{CB}$, they are able to extract cylindrical cores, capturing them either with a suction mechanism or by a characteristic feature of the tip.

- Screw or helical tip needles: fine or large (10-14G) needles with a peculiar tip, in which the biopsy needle is inserted inside the lesion by rotating the tip and the tissue is captured into an outer cannula.

- Trephine-type needle: large-size needles, used for sclerotic bone lesions; they consist of an outer trocar inserted and left in place into the lesion, to allow multiple passes as for the coaxial technique

- Coaxial needle: used for coaxial technique; hollow needle, 9-19G, depending on the size of biopsy needle. The introducer needle is characterized by a blunt-tip to avoid damage to nontarget nearby critical structures; it is inserted and left in place after removing the inner stylet, allowing multiple passes of biopsy needles for multiple specimen collection or combination of FNAB cytology and CB histology from the same access [21]. 
- Steerable needle: recently introduced; flexible needles, that are potentially able to reach targets not accessible using traditional needles. They can be pre-curved or manually deformed. Their role is yet to be assessed.

\section{Sample aspiration or capturing}

- Syringe (usually 10-30mL): attached to biopsy needle, it is traditionally used for FNAB. During suction, the needle is oscillated with short "in-and-out" movements. Before withdrawing the needle, the suction has to be discontinued to prevent aspiration of cells from the needle tract.

- Oscillating biopsy needle: used for FNAB; the oscillations associated with suction can increase the sample size.

- Vacuum-assisted biopsy needle: special systems allow the creation of vacuum inside a CB needle to draw long cores of tissue into the centre of the needle.

- Rotating CB needle: the inner needle rotates and oscillates to obtain a uniform tissue sample.

\section{Equipment for specimen collection}

The equipment required for specimen collection and preparation must be available and prepared before the procedure. This includes, among the others: sterile containers, slides for smears, fixatives, and containers with formalin fixative or saline.

\section{Procedural Features and Variations of the Technique Procedural steps in US guidance}

Before PNB, a full US examination should be performed to evaluate the target organ and lesion, and plan and measure the access route. Colour-Doppler US may be useful to identify relevant vascular structures.

Basic principle of US guided PNB is to align the scan plane, showing the target, with the needle plane showing the needle during the insertion [9]. Needle can be inserted parallel or perpendicular to the transducer. With the parallel insertion, it is possible to use a free-hand or a needle-guided technique, while the perpendicular insertion can only be performed by free-hand technique. 
The needle-guided insertion consists of a plastic or metal device, with a "channel" for the needle, which is attached to the transducer and is able to provide a computer-generated path to the lesion with a fixed angle. Compared to the free-hand technique, the guided technique seems to be faster and more efficient; especially for less experienced operators as it allows almost single puncture, also, for deep targets [22]. However, this technique is limited by a fixed angle, reducing the freedom in needle angulation and manipulation during insertion; thus, the free-hand modality is still frequently used, especially by experienced operators [18].

During the insertion, the needle-tip should always be clearly visualized as an echogenic complex. Needle-tip visualization depends on several factors, such as the needle type and size and scanning angulation, and can be facilitated by simple manoeuvres, such as shaking the needle, moving the stylet within the needle or even injecting a small amount of saline or lidocaine [18]. Particular care should be paid to avoid air injection that may impair the proper visualization of the target area. The puncture should be as rapid as possible, during breath-hold when needed, to reduce damage of organ capsule and bleeding.

\section{Procedural steps in CT guidance}

A preliminary CT scan is obtained, limited to the volume including the target lesion. When needed, CT can be performed after intravenous contrast media administration to visualize the target and the surrounding structures.

The puncture tract is selected on axial scans or on multiplanar reformations when the path has to be angulated to the z-direction; when a double-angulated puncture is needed, the gantry can be tilted according to the available CT equipment capabilities, to provide images parallel to the direction of the access path. The path length and angle are measured on the CT scan and the skin access point is marked with the gantry laser, a radiopaque marker (for instance an injection needle) or using a radiopaque grid positioned on the patient before the preliminary CT.

After skin preparation and incision, the needle is advanced into the subcutaneous tissues incrementally to assure proper needle angulation and direction. Using standard CT guidance, operators must leave the CT room to check needle position at each needle's advancement. 
Puncture of risky structures (pleura and solid organ capsule) should be performed in a single deliberate motion directed at the target in a single breath-hold to reduce incidence of complications.

\section{- CT Fluoroscopy}

In CT fluoroscopy, fast images are acquired with reduced spatial resolution, and concurrently reconstructed and displayed, allowing real-time visualization of the needle advancement. Compared to conventional CT, if available, CT fluoroscopy represents a valid guiding method that reduces procedural time and number of needle passes, thus resulting in reduced complications $[23,24]$.

CT fluoroscopy can be continuous or intermittent. When continuous CT-fluoroscopy is used, CT images are acquired continuously during needle advancement thus exposing operators and patients to high radiation doses [23-26]. As opposite, in intermittent CT-fluoroscopy, the operators stand at the side of the gantry where a pedal is available to acquire CT images; the operators' radiation dose becomes minimal or null, since the gantry width is generally enough to block the vast majority of the radiation dose.

\section{Procedural steps in uncommon guidance}

\section{- MR guidance}

MR guidance can be extremely useful for lesions not detectable with other imaging modalities [27]; it is gaining increasing acceptance for specific indications, such as breast and prostate lesions [28, 29]. Special nonmagnetic alloy needles are needed for MR-guided PNB. Procedure steps are similar to those described for CT guidance (patient positioning and immobilization, access identification, monitoring of needle advancement). However, technical complexity of MR guidance relies mostly on the understanding of the used MR equipment and sequences that influence the visualization of the target and the puncture needle [30]. In fact, susceptibility artefacts, with apparent widening of the needle and reduced visualization of the surrounding structure, are more prominent when using higher MR field strengths, lower sampling bandwidth and rapid gradient-echo sequences. Thus, when the target is small and close to risky structures, using turbo spin-echo sequences and setting the frequency-encoding axis parallel to the needle shaft may allow artefact reduction. 
There are several methods used to guide the procedure. Freehand and stereotactic techniques are suited for open magnets systems when the operator has direct access to the patient. In the freehand technique, short TR / short TE gradient-echo sequences allow realtime monitoring of the procedure with a possibility of scanning the patient in one or multiple orthogonal planes. In close-bore systems, when the radiologist has a limited access to patient, augmented reality and image fusion techniques have been developed $[20,31]$; their major limitations are however represented by movement mismatches that may occur between pre-procedural image registration and the time of the actual needle insertion.

\section{$-P E T / C T$}

$\mathrm{PET} / \mathrm{CT}$ has been proposed to guide PNB in the setting of metabolically active lesions not evident using other images modalities, or located within areas of necrosis, fibrosis of atelectasis [32]. Since FDG uptake is not specific for cancer, strict collaboration with nuclear medicine physicians is mandatory for a proper interpretation of PET/CT in order to increase PNB success.

$\mathrm{PET} / \mathrm{CT}$ guidance can be performed either using a conventional CT scanner by registering pre-procedural PET/CT images with intra-procedural CT scans or by using the CT elements of the integrated PET/CT system In the latter situation, operators' radiation exposure may be consistent, representing a major drawback of the technique.

\section{PNB Techniques}

\section{1) Coaxial technique}

A guide needle, larger than the biopsy needle (typically 9-19G) is advanced under image guidance, reaching the edge of the target. The inner stylet is removed, with the operator's finger placed over the lumen to prevent air aspiration. A biopsy needle is then introduced into the guide needle coaxially. This technique allows the collection of multiple specimens in a single puncture [33] and may prevent possible tumour cells seeding along the needle tract by re-inserting the inner stylet of the coaxial needle before removal [34, 35]. In order to biopsy different portions of the target, position of the guiding needle can be modified by manual steering; side exiting guide needles are also available. 
Compared to the non-coaxial method, the coaxial technique does not increase the rate of complications [36, 37]. Moreover, in specific situations such as in transperineal prostate biopsy, it can reduce procedural time and procedure-related pain [38].

\section{2) Tandem technique}

A small gauge needle is first introduced into the lesion under image guidance. A second biopsy needle is then advanced parallel to the first reference device. This system has the disadvantage of requiring multiple punctures.

\section{3) Fine needle aspiration biopsy (FNAB)}

FNA uses a small, hollow (18-25G) needle with inner stylet. Once in place, the stylet is removed, a syringe (usually $10-30 \mathrm{~mL}$ ) is attached to the biopsy needle, and cells are aspirated oscillating the needle either manually or automatically to increase the sample size. Before withdrawing the needle, suction has to be discontinued to prevent aspiration of cells from the needle tract.

\section{4) Core needle biopsy (CB)}

For CB, the needle (9-20G) has a cutting edge able to extract tissue for histologic analysis, with different mechanisms:

- Tru-Cut needles are composed of an outer cannula and inner notched trocar, in which a tissue specimen is cut, trapped and withdrawn. Before introducing the needle, the inner trocar is withdrawn into the outer cannula. Once the needle is in place, the trocar is advanced and its correct position is checked. The cutting system is then activated according to the manufacturer's indications. The inner trocar can be advanced manually or automatically whereas the outer needle is usually moved automatically. The notched trocar containing the specimen is withdrawn into the outer cannula, before removal of the device. - In the so-called full-core biopsy needles, after inserting the needle with the inner trocar up to the lesion margin, the outer cutting cannula is manually or automatically pushed into the pathologic tissue, and the core can be harvested by rotating/torqueing the needle tip or using another capture/trapping cannula system. 
- In more recently designed screw or helical needles, the tip is introduced through the outer cutting cannula, engaging the lesion by using a clockwise motion. Sample is collected by advancing the outer cutting cannula forward over the biopsy needle tip.

\section{5) Puncture site compression or embolization}

Direct manual compression of the puncture site for seconds to minutes is required to prevent bleeding.

When using the coaxial technique, puncture site plugging has been proposed, particularly in procedures at higher bleeding risk [39] and to reduce the rate of PNX [40, 41]. The biopsy needle is removed and the embolic material is injected through the guiding needle, embolising the biopsy site and the needle path and avoiding non-target structures. Usually, embolization is performed using gelfoam slurry of plugs that are pushed either with saline injection, or using the inner needle. Some authors have proposed the use of 1-3 $\mathrm{ml}$ of saline or autologous blood clot to seal the needle tract in lung biopsy $[42,43]$. Since the guiding needle should be kept in place for the shortest time possible to avoid injuries of nearby structures, it is recommended to select and prepare the embolic material in advance.

\section{Specimen collection and preparation}

\section{- FNAB:}

The specimen is smeared_on glass slides and fixed according to institutional pathology laboratory preference (air dried smears, ethanol or methanol fixed smears, and smears fixed with coating spray containing ethanol and polyethylene glycol are all common practices). - CB:

Specimens may be placed in saline or $10 \%$ formalin depending on Institutional pathology laboratory preference. In general, for histopathological examination the specimen is fixed in formalin, while for bacteriological analysis the sample is sent in saline for culture. All samples must be correctly labelled and sent to the laboratory together with all relevant medical information [5].

\section{Post-procedural Care}

Immediately after the procedure, patient has to be imaged for potential immediate complications using the same imaging modality used for PNB guidance. 
In US-guided procedures, further X-ray or CT examinations may be required when PNX or bleeding are suspected.

The vast majority of complications occur within 4-6 hours following PNB. Thus, clinical observation, pain evaluation, using standard numeric rating scales, and vital signs monitoring are required for 1-6 hours following the procedure, depending upon its location and complexity. Blood count check is recommended in procedures at higher risk of bleeding. Imaging control (whether US, X-rays or CT) should always be obtained and documented before discharge.

When discharged, patient must be fully informed about post-procedural care, potential late complications and their symptoms, be provided with guidance for initial management and prompt access to appropriate care [5].

Analgesics (typically, paracetamol or NSAIDs) are prescribed when needed. Also, topical local anaesthetic creams or sprays may be useful for local, superficial pain.

When indicated, clinical and imaging follow-up should be scheduled the time of discharge [5].

\section{Follow-up}

Result of PNB should be evaluated and discussed by the multidisciplinary team involved in patient's management, including a referring physician, an IR, a pathologist and, when indicated, a surgeon and/or a microbiologist to define subsequent treatment and/or followup [15].

When biopsy results do not show a diagnostic, a repeated biopsy should be considered, simultaneously discussing different approaches, techniques or guidance modalities. Also surgical biopsy should be discussed among the possible options.

Results of PNB and of the multidisciplinary discussion will be finally communicated to the patient with a most proper modality, according to the Institutional policy [5].

\section{Outcome}

Procedural features, outcomes and complications of PNB in different anatomical districts are summarized in Supplementary tables [14, 44-63].

\section{a. Effectiveness}


Overall reported diagnostic technical success rate of PNB ranges from $70 \%$ to $96 \%$ [44]; however, it varies greatly depending upon the size and location of the target, benign or malignant nature of the lesion, number of samples obtained, availability of an on-site cytopathologist, IRs' and pathologists' experience, equipment availability. The Society of Interventional Radiology (SIR) quality improvement guidelines for PNB suggested using a threshold of 70\%-75\% for the technical success rate for internal auditing [44].

Clinical success of PNB can be measured as the usefulness of the procedure in terms of improvement of patient care determined by the result of biopsy, including quality of life (QoF). As examples, in the era of personalized cancer care, selection of patients for targeted or immune-targeted therapies as well as recruitment in clinical trials can be a favourable outcome of PNB. Similarly, PNB reaches its clinical goal when surveillance is chosen as an alternative to the active treatments on basis of a diagnosis of low-grade malignancy in selected patients (e.g. prostate or renal cancer in elderly patients).

\section{b. Complications}

PNB is usually considered a minimally invasive and safe procedure, with a procedure-related mortality rate lower than $0.05 \%$.

Complications are divided into major and minor (Appendix A), and into generic (common for all biopsies, such as bleeding, infection, perforation, unintended organ injury and tract seeding) and organ-specific (such as pneumothorax, hemoptysis, air embolism, hematuria). SIR quality improvement guidelines suggest a $2 \%$ quality improvement threshold for the overall incidence of major complications after PNB [44].

\section{Complications' management}

Ideally all possible complications should be anticipated to allow early recognition and treatment; this implies prompt access to resuscitation equipment and drugs, imaging techniques, interventional radiology and surgical procedures [16].

\section{- Bleeding}

Significant bleeding (grade 3 or greater) is a rare complication of PNB. In a single centre, retrospective review of over 15,000 biopsies, Atwell et al. reported $0.5 \%$ of cases of significant haemorrhage within 3 months, varying according to biopsy site from $0.7 \%$ for the kidney to $0.1 \%$ in pancreatic biopsy [64]. 
Bleeding can be diagnosed during or immediately after the procedure by imaging or linked to the presence of pain, tachycardia and hypotension. Clinical severity and potential bleeding site should be immediately evaluated, and manual compression should be applied whenever possible. Based on the severity and the localization of the bleeding, assessed clinically and by imaging, following treatments can be considered:

1) Reverse any anticoagulation if required and considered safe;

2) Endovascular embolization for clinically relevant arterial bleeding in solid organs or bowel;

3) Endovascular deployment of covered stents for injured large vessels;

4) Surgery, when endovascular treatment is not feasible or unsuccessful, or for hemodynamically unstable patients.

- $\underline{\text { Infection }}$

Severity and location of infection should be evaluated clinically and by imaging. Samples for culture are required for a final diagnosis and treatment with appropriate antibiotics.

Drainage should be considered for abscesses and collections.

\section{- Perforation}

The majority of organs tolerate puncture well, with no substantial sequelae. In case of a bowel transgression, close monitoring is required due to a risk of peritonitis and prophylaxis may be considered (antibiotic and parenteral alimentation).

\section{- Pneumothorax}

PNX represents a frequent complication of lung biopsy, with a pooled rate reported in a recent meta-analysis of $25.3 \%$ for CB and $18.8 \%$ for FNAB [65]. However, only a minority of cases require an intervention (5.6\% after CB and $4.3 \%$ after FNAB) [65].

Several measures can be taken to reduce the incidence of PNX requiring chest. Besides proper patient instructions during the procedure, and an adequate planning of the access site (reducing the number of crosses of pleural surface and avoiding fissurae and bullae)[66], some authors recommend positioning the patient with the puncture side down for at least one hour immediately after the introducer needle removal after the biopsy; that should reduce aeration of the punctured lung. Also, plugging of the needle tract has been proposed to prevent PNX $[40,41,43]$.

When using the coaxial technique, a CT check should be performed prior to the removal of the introducing needle; if PNX develops, the needle can be withdrawn into the pleural space and air can be manually aspirated using a three-ways valve and a $50-\mathrm{mL}$ Luer-lock syringe. 
Chest tube placement is indicated in symptomatic PNX or when PNX continues to enlarge. A 6- to 9-French catheter is placed under the CT guidance and attached to a one-way Heimlich valve, or to underwater seal drainage device and wall suction. Larger catheters could be used in patients with concomitant pleural effusion. The tube is generally removed after 1-2 days. Chest X-ray should be obtained after chest tube removal.

\section{- Air embolism}

Air embolism is a rare but potentially fatal complication due to the puncture of a pulmonary vein that causes air to be being sucked in and enter the systemic circulation, subsequently causing ictus, seizures or other neurologic symptoms, coronary ischemia or cardiopulmonary collapse.

To prevent air embolism, the introducer needle should always be occluded by the inner stylet or a finger, and the patient should avoid coughing and deep breathing during biopsy. If air embolism occurs, the needle is immediately removed, the patient is placed in a mild Trendelenburg position to avoid cerebral embolization and $100 \%$ oxygen is administered to accelerate bubble absorption [67]. Early hyperbaric oxygen therapy is recommended.

\section{- Tract seeding}

Tumour seeding occurs when malignant cells are deposited along the needle path. It is a rare, yet catastrophic complication, particularly when it occurs in otherwise potentially curable oncologic patients, such as surgical candidates. The risk of seeding may be influenced by the needle size and the number of needle passes, and it varies according to the tumour type and location.

The risk is negligible after biopsy of intrapulmonary nodules $(0.061 \%$ in a Japanese review of almost 10,000 percutaneous lung biopsies) [68] and renal tumours (below 0.01\%) [69], while it increases in liver biopsies. The reported overall risk of needle tract seeding following biopsy of hepatocellular carcinoma is around $2.3-2.7 \%$, and can be reduced to $0.7-1.4 \%$ when combining biopsy with percutaneous ablation in the same session [70, 71]. Needle tract seeding becomes a major issue when dealing with colorectal liver metastasis, with a reported incidence of $16-19 \%$, in operable patient, and a not negligible impacting on survival $[72,73]$. The risk of seeding is also substantial in primary pleural malignancy (approximately 4\%) [74] and pancreatic carcinoma. Thus, in all these clinical conditions risks and benefits of PNB should be carefully evaluated, particularly in potentially resectable patients and when endoscopic biopsy can be performed as an alternative. 
If the needle track metastasis is isolate, wide en bloc resection should be considered.

\section{Conclusions}

PNB is an established procedure, useful in numerous clinical conditions. Safety and technical efficacy are widely demonstrated. However, they are strongly dependent on several patientrelated and team-related variables. Thus, qualified IRs should always perform PNB following clearly identified indications, in an appropriate environment and in the setting of a multidisciplinary pre- and post-procedural management [15]. In the precision medicine era with personalized cancer care, image-guided PBN has an evolving role to meet the future patients' needs [1].

\section{Compliance with Ethical Standards}

Conflict of Interest: All authors declare that they have no conflicts of interest.

\section{References}

1) Tam AL, Lim HJ, Wistuba II, Tamrazi A, Kuo MD, Ziv E, et al. Image-Guided Biopsy in the Era of Personalized Cancer Care: Proceedings from the Society of Interventional Radiology Research Consensus Panel. J Vasc Interv Radiol 2016;27(1):8-19. doi: 10.1016/j.jvir.2015.10.019.

2) Solomon SB, Zakowski MF, Pao W, Thornton RH, Ladanyi M, Kris MG, et al. Core needle lung biopsy specimens: adequacy for EGFR and KRAS mutational analysis. AJR Am J Roentgenol. 2010;194(1):266-269. doi: 10.2214/AJR.09.2858.

3) Sacks D, McClenny TE, Cardella JF, Lewis CA. Society of Interventional Radiology clinical practice guidelines. J Vasc Interv Radiol. 2003;14: S199-S202.

4) Taslakian B, Georges Sebaaly M, Al-Kutoubi A. Patient Evaluation and Preparation in Vascular and Interventional Radiology: What Every Interventional Radiologist Should Know (Part 1: Patient Assessment and Laboratory Tests). Cardiovasc Intervent Radiol. 2016;39(3):325-333.

5) Lee MJ, Fanelli F, Haage P, Hausegger K, Van Lienden KP. Patient safety in interventional radiology: a CIRSE IR checklist. Cardiovasc Intervent Radiol. 2012;35(2):244-246. doi: 10.1007/s00270-011-0289-5.

6) Douketis JD, Spyropoulos AC, Spencer FA, Mayr M, Jaffer AK, Eckman MH et al; American College of Chest Physicians. Perioperative management of antithrombotic therapy: Antithrombotic Therapy and Prevention of Thrombosis, 9th ed: American College of Chest Physicians Evidence-Based Clinical Practice Guidelines. Chest. 2012;141(2 Suppl):e326Se350S. doi: 10.1378/chest.11-2298. 
7) Patel IJ, Davidson JC, Nikolic B, Salazar GM, Schwartzberg MS, Walker TG, et al; Standards of Practice Committee, with Cardiovascular and Interventional Radiological Society of Europe (CIRSE) Endorsement. Consensus guidelines for periprocedural management of coagulation status and hemostasis risk in percutaneous image-guided interventions. J Vasc Interv Radiol. 2012;23(6):727-736. doi: 10.1016/j.jvir.2012.02.012.

8) Hinojar R, Jiménez-Natcher JJ, Fernández-Golfín C, Zamorano JL. New oral anticoagulants: a practical guide for physicians. Eur Heart J Cardiovasc Pharmacother. 2015;1(2):134-145. doi: 10.1093/ehjcvp/pvv002.

9) Lorentzen T, Nolsøe CP, Ewertsen C, Nielsen MB, Leen E, Havre RF, et al; EFSUMB. EFSUMB Guidelines on Interventional Ultrasound (INVUS), Part I. General Aspects (long Version). Ultraschall Med. 2015;36(5):E1-14. doi: 10.1055/s-0035-1553593.

10) Zani EL, Clark OA, Rodrigues Netto N Jr. Antibiotic prophylaxis for transrectal prostate biopsy. Cochrane Database Syst Rev. 2011 May 11;(5):CD006576. doi: 10.1002/14651858.CD006576.pub2.

11) Cussans A, Somani BK, Basarab A, Dudderidge TJ. The role of targeted prophylactic antimicrobial therapy before transrectal ultrasonography-guided prostate biopsy in reducing infection rates: a systematic review. BJU Int. 2016;117(5):725-731. doi: 10.1111/bju.13402.

12) McGrath A, Sabharwal T. General Principles of Biopsy and Drainage. In: Gervais DA, Sabharwal T, editors. Interventional Radiology Procedures in Biopsy and Drainage. London: Springer-Verlag; 2011. pp: 1-10.

13) Gupta S, Krishnamurthy S, Broemeling LD, Morello FA Jr, Wallace MJ, Ahrar K, et al. Small $(</=2-\mathrm{cm})$ subpleural pulmonary lesions: short- versus long-needle-path CT-guided biopsy comparison of diagnostic yields and complications. Radiology 2005; 234:631-637.

14) Sainani NI, Arellano RS, Shyn PB, Gervais DA, Mueller PR, Silverman SG. The challenging image-guided abdominal mass biopsy: established and emerging techniques 'if you can see it, you can biopsy it'. Abdom Imaging. 2013;38(4):672-696. doi: 10.1007/s00261-013-9980-0.

15) Tsetis D, Uberoi R, Fanelli F, Roberston I, Krokidis M, van Delden O, et al. The Provision of Interventional Radiology Services in Europe: CIRSE Recommendations. Cardiovasc Intervent Radiol. 2016;39(4):500-506. doi: 10.1007/s00270-016-1299-0.

16) ACR-SIR-SPR Practice Parameter for the Performance of Image-Guided Percutaneous Needle Biopsy (PNB) Res. 35 - 2013, Amended 2014 (Res. 39). Available from: http://www.acr.org/ /media/ACR/Documents/PGTS/guidelines/PNB.pdf

17) Tam AL, Kim ES, Lee JJ, Ensor JE, Hicks ME, Tang $X$, et al. Feasibility of image-guided transthoracic core-needle biopsy in the BATTLE lung trial. J Thorac Oncol. 2013;8(4):436-442. doi: 10.1097/JTO.0b013e318287c91e.

18) Gupta S. New techniques in image-guided percutaneous biopsy. Cardiovasc Intervent Radiol. 2004;27(2):91-104.

19) Abi-Jaoudeh N, Kruecker J, Kadoury S, Kobeiter H, Venkatesan AM, Levy E, et al. Multimodality image fusion-guided procedures: technique, accuracy, and applications. Cardiovasc Intervent Radiol. 2012;35(5):986-998

20) Chehab MA, Brinjikji W, Copelan A, Venkatesan AM. Navigational Tools for Interventional Radiology and Interventional Oncology Applications. Semin Intervent Radiol. 2015;32(4):416427. doi: 10.1055/s-0035-1564705. 
21) Aviram G, Greif J, Man A, Schwarz Y, Marmor S, Graif M, Blachar A. Diagnosis of intrathoracic lesions: are sequential fine-needle aspiration (FNA) and core needle biopsy (CNB) combined better than either investigation alone? Clin Radiol. 2007;62(3):221-226.

22) Shabana W, Kielar A, Vermani V, Fernandes DD, Antoniscu R, Schweitzer M. Accuracy of sonographically guided biopsy using a freehand versus needle-guided technique: computed tomographic correlation study. J Ultrasound Med. 2013;32(3):535-540.

23) Kim GR, Hur J, Lee SM, Lee HJ, Hong YJ, Nam JE, et al. CT fluoroscopy-guided lung biopsy versus conventional CT-guided lung biopsy: a prospective controlled study to assess radiation doses and diagnostic performance. Eur Radiol. 2011;21(2):232-239.

24) Heck SL, Blom P, Berstad A. Accuracy and complications in computed tomography fluoroscopy-guided needle biopsies of lung masses. Eur Radiol. 2006;16(6):1387-1392.

25) Prosch H, Stadler A, Schilling M, Bürklin S, Eisenhuber E, Schober E et al. CT fluoroscopyguided vs. multislice CT biopsy mode-guided lung biopsies: accuracy, complications and radiation dose. Eur J Radiol. 2012;81(5):1029-1033.

26) Mammarappallil JG, Hiatt KD, Ge Q, Clark HP. Computed tomography fluoroscopy versus conventional computed tomography guidance for biopsy of intrathoracic lesions: a retrospective review of 1143 consecutive procedures. J Thorac Imaging. 2014;29(6):340-343. doi: 10.1097/RTI.0000000000000109.

27) Lü Y, Fritz J, Li C, Liu M, Lee P, Wu L, et al. Magnetic resonance imaging-guided percutaneous biopsy of mediastinal masses: diagnostic performance and safety. Invest Radiol. 2013;48(6):452-457. doi: 10.1097/RLI.0b013e31827a4a17.

28) Verheyden C, Pages-Bouic E, Balleyguier C, Cherel P, Lepori D, Laffargue G, et al. Underestimation Rate at MR Imaging-guided Vacuum-assisted Breast Biopsy: A MultiInstitutional Retrospective Study of 1509 Breast Biopsies. Radiology. 2016 Jun 29:151947.

29) Woodrum DA, Gorny KR, Greenwood B, Mynderse LA. MRI-Guided Prostate Biopsy of Native and Recurrent Prostate Cancer. Semin Intervent Radiol. 2016;33(3):196-205. doi: 10.1055/s-0036-1586151.

30) Weiss CR, Nour SG, Lewin JS. MR-guided biopsy: a review of current techniques and applications. J Magn Reson Imaging. 2008 Feb;27(2):311-325.

31) Muthigi A, George AK, Sidana A, Kongnyuy M, Simon R, Moreno V, et al. Missing the Mark: Prostate Cancer Upgrading By Systematic Biopsy over MRI/TRUS Fusion Biopsy. J Urol. 2016 Aug 28. pii: S0022-5347(16)31193-4. doi: 10.1016/j.juro.2016.08.097.

32) El-Haddad G. PET-Based Percutaneous Needle Biopsy. PET Clin. 2016;11(3):333-349. doi: 10.1016/j.cpet.2016.02.009.

33) Stewart CJ, Coldewey J, Stewart IS. Comparison of fine needle aspiration cytology and needle core biopsy in the diagnosis of radiologically detected abdominal lesions. J Clin Pathol. 2002;55(2):93-97.

34) Maturen KE, Nghiem HV, Marrero JA, Hussain HK, Higgins EG, Fox GA, et al. Lack of tumor seeding of hepatocellular carcinoma after percutaneous needle biopsy using coaxial cutting needle technique. AJR Am J Roentgenol. 2006;187(5):1184-1187.

35) Robertson EG, Baxter G. Tumour seeding following percutaneous needle biopsy: the real story! Clin Radiol. 2011;66(11):1007-1014. doi: 10.1016/j.crad.2011.05.012. 
36) Hatfield MK, Beres RA, Sane SS, Zaleski GX. Percutaneous imaging-guided solid organ core needle biopsy: coaxial versus noncoaxial method. AJR Am J Roentgenol. 2008;190(2):413-417. doi: 10.2214/AJR.07.2676.

37) Nour-Eldin NE, Alsubhi M, Emam A, Lehnert T, Beeres $M$, Jacobi $V$, et al. Pneumothorax Complicating Coaxial and Non-coaxial CT-Guided Lung Biopsy: Comparative Analysis of Determining Risk Factors and Management of Pneumothorax in a Retrospective Review of 650 Patients. Cardiovasc Intervent Radiol. 2016;39(2):261-270. doi: 10.1007/s00270-0151167-3.

38) Babaei Jandaghi A, Habibzadeh H, Falahatkar S, Heidarzadeh A, Pourghorban R. Transperineal Prostate Core Needle Biopsy: A Comparison of Coaxial Versus Noncoaxial Method in a Randomised Trial. Cardiovasc Intervent Radiol. 2016 Aug 2. [Epub ahead of print]

39) Zins M, Vilgrain V, Gayno S, Rolland Y, Arrivé L, Denninger MH, et al. US-guided percutaneous liver biopsy with plugging of the needle track: a prospective study in 72 highrisk patients. Radiology. 1992;184(3):841-843.

40) Tran AA, Brown SB, Rosenberg J, Hovsepian DM. Tract embolization with gelatin sponge slurry for prevention of pneumothorax after percutaneous computed tomography-guided lung biopsy. Cardiovasc Intervent Radiol. 2014;37(6):1546-1553. doi: 10.1007/s00270-0130823-8.

41) Baadh AS, Hoffmann JC, Fadl A, Danda D, Bhat VR, Georgiou N, et al. Utilization of the track embolization technique to improve the safety of percutaneous lung biopsy and/or fiducial marker placement. Clin Imaging. 2016;40(5):1023-1028. doi: 10.1016/j.clinimag.2016.06.007.

42) Li Y, Du Y, Luo TY, Yang HF, Yu JH, Xu XX, et al. Usefulness of normal saline for sealing the needle track after CT-guided lung biopsy. Clin Radiol. 2015;70(11):1192-1197. doi: 10.1016/j.crad.2015.06.081.

43) Lang EK, Ghavami R, Schreiner VC, Archibald S, Ramirez J. Autologous blood clot seal to prevent pneumothorax at CT-guided lung biopsy. Radiology 2000;216(1):93-96.

44) Gupta S, Wallace MJ, Cardella JF, Kundu S, Miller DL, Rose SC; Society of Interventional Radiology Standards of Practice Committee. Quality improvement guidelines for percutaneous needle biopsy. J Vasc Interv Radiol. 2010;21(7):969-975. doi: 10.1016/j.jvir.2010.01.011.

45) Gupta S, Henningsen JA, Wallace MJ, Madoff DC, Morello FA Jr, Ahrar K, et al. Percutaneous biopsy of head and neck lesions with CT guidance: various approaches and relevant anatomic and technical considerations. Radiographics. 2007;27(2):371-390.

46) Learned KO, Lev-Toaff AS, Brake BJ, Wu RI, Langer JE, Loevner LA. US-guided Biopsy of Neck Lesions: The Head and Neck Neuroradiologist's Perspective. Radiographics. 2016;36(1):226-243. doi: 10.1148/rg.2016150087.

47) Zhang HF, Zeng XT, Xing F, Fan N, Liao MY. The diagnostic accuracy of CT-guided percutaneous core needle biopsy and fine needle aspiration in pulmonary lesions: a metaanalysis. Clin Radiol. 2016;71(1):e1-e10. doi: 10.1016/j.crad.2015.09.009. 
48) Gupta S, Seaberg K, Wallace MJ, Madoff DC, Morello FA Jr, Ahrar K, et al. Imaging-guided percutaneous biopsy of mediastinal lesions: different approaches and anatomic considerations. Radiographics. 2005;25(3):763-788.

49) Rockey DC, Caldwell SH, Goodman ZD, Nelson RC, Smith AD; American Association for the Study of Liver Diseases. Liver biopsy. Hepatology. 2009;49(3):1017-1044. doi: 10.1002/hep.22742.

50) Kalambokis G, Manousou P, Vibhakorn S, Marelli L, Cholongitas E, Senzolo M, et al. Transjugular liver biopsy--indications, adequacy, quality of specimens, and complications--a systematic review. J Hepatol. 2007;47(2):284-294.

51) Howlett DC, Drinkwater KJ, Lawrence D, Barter S, Nicholson T. Findings of the UK national audit evaluating image-guided or image-assisted liver biopsy. Part I. Procedural aspects, diagnostic adequacy, and accuracy. Radiology. 2012;265(3):819-831. doi: 10.1148/radiol.12111562.

52) Howlett DC, Drinkwater KJ, Lawrence D, Barter S, Nicholson T. Findings of the UK national audit evaluating image-guided or image-assisted liver biopsy. Part II. Minor and major complications and procedure-related mortality. Radiology. 2013;266(1):226-235. doi: 10.1148/radiol.12120224.

53) Lipnik AJ, Brown DB. Image-Guided Percutaneous Abdominal Mass Biopsy: Technical and Clinical Considerations. Radiol Clin North Am. 2015;53(5):1049-1059. doi: 10.1016/j.rcl.2015.05.007.

54) Mclnnes MD, Kielar AZ, Macdonald DB. Percutaneous image-guided biopsy of the spleen: systematic review and meta-analysis of the complication rate and diagnostic accuracy. Radiology. 2011 Sep;260(3):699-708. doi: 10.1148/radiol.11110333.

55) Rajiah P, Sinha R, Cuevas C, Dubinsky TJ, Bush WH Jr, Kolokythas O. Imaging of uncommon retroperitoneal masses. Radiographics. 2011;31(4):949-976. doi: 10.1148/rg.314095132.

56) Marconi L, Dabestani S, Lam TB, Hofmann F, Stewart F, Norrie J, et al. Systematic Review and Meta-analysis of Diagnostic Accuracy of Percutaneous Renal Tumour Biopsy. Eur Urol. 2016;69(4):660-673. doi: 10.1016/j.eururo.2015.07.072.

57) Bancos I, Tamhane S, Shah M, Delivanis DA, Alahdab F, Arlt W, et al. DIAGNOSIS OF ENDOCRINE DISEASE: The diagnostic performance of adrenal biopsy: a systematic review and meta-analysis. Eur J Endocrinol. 2016;175(2):R65-80. doi: 10.1530/EJE-16-0297.

58) Vanderveen KA, Thompson SM, Callstrom MR, Young WF Jr, Grant CS, Farley DR, et al. Biopsy of pheochromocytomas and paragangliomas: potential for disaster. Surgery 2009;146(6):1158-1166. doi: 10.1016/j.surg.2009.09.013.

59) Ukimura O, Coleman JA, de la Taille A, Emberton M, Epstein JI, Freedland SJ, et al. Contemporary role of systematic prostate biopsies: indications, techniques, and implications for patient care. Eur Urol. 2013;63(2):214-230. doi: 10.1016/j.eururo.2012.09.033.

60) Jiang X, Zhu S, Feng G, Zhang Z, Li C, Li H, et al. Is an initial saturation prostate biopsy scheme better than an extended scheme for detection of prostate cancer? A systematic review and meta-analysis. Eur Urol. 2013;63(6):1031-1039. doi:

10.1016/j.eururo.2013.01.035. 
61) Pua BB , Solomon SB. Lymph Node Biopsy. In: Gervais DA, Sabharwal T, editors. Interventional Radiology Procedures in Biopsy and Drainage. London: Springer-Verlag; 2011. pp: 73-79.

62) Traina F, Errani C, Toscano A, Pungetti C, Fabbri D, Mazzotti A, Donati D, Faldini C. Current concepts in the biopsy of musculoskeletal tumors. J Bone Joint Surg Am. 2015 Jan 7;97(1):e7.

63) Huang AJ, Kattapuram SV. Musculoskeletal neoplasms: biopsy and intervention. Radiol Clin North Am. 2011;49(6):1287-1305, vii. doi: 10.1016/j.rcl.2011.07.010.

64) Atwell TD, Smith RL, Hesley GK, Callstrom MR, Schleck CD, Harmsen WS, et al. Incidence of bleeding after 15,181 percutaneous biopsies and the role of aspirin. AJR Am J Roentgenol. 2010;194(3):784-789. doi: 10.2214/AJR.08.2122.

65) Heerink WJ, de Bock GH, de Jonge GJ, Groen HJ, Vliegenthart R, Oudkerk M. Complication rates of CT-guided transthoracic lung biopsy: meta-analysis. Eur Radiol 2017;27(1):138-148.

66) Moreland A, Novogrodsky E, Brody L, Durack J, Erinjeri J, Getrajdman G, et al. Pneumothorax with prolonged chest tube requirement after CT-guided percutaneous lung biopsy: incidence and risk factors. Eur Radiol. 2016;26(10):3483-3491. doi: 10.1007/s00330015-4200-7.

67) Wu CC, Maher MM, Shepard JA. Complications of CT-guided percutaneous needle biopsy of the chest: prevention and management. AJR Am J Roentgenol. 2011;196(6):W678-682. doi: 10.2214/AJR.10.4659.

68) Tomiyama N, Yoshifumi Y, Yasuo N, et al. CT-guided needle biopsy of lung lesions: a survey of severe complications based on 9783 biopsies in Japan. Eur J Radiol 2006;59:60-64

69) Herts B, Baker M. The current role of percutaneous biopsy in the evaluation of renal masses. Curr Opin Urol 2000;10:105-109 .

70) Silva MA, Hegab B, Hyde C, Guo B, Buckels JA, Mirza DF. Needle track seeding following biopsy of liver lesions in the diagnosis of hepatocellular cancer: a systematic review and meta-analysis. Gut 2008;57:1592-1596.

71) Stigliano R, Marelli L, Yu D, Davies N, Patch D, Burroughs AK. Seeding following percutaneous diagnostic and therapeutic approaches for hepatocellular carcinoma. What is the risk and the outcome? Seeding risk for percutaneous approach of HCC. Cancer Treat Rev 2007;33:437-447.

72) Rodgers $M$, Collinson R, Desai $S$, et al. Risk of dissemination with biopsy of colorectal liver metastases. Dis Colon Rectum 2003;46:454-459.

73) Jones $O$, Rees $M$, John $T$, et al. Biopsy of resectable colorectal liver metastases causes tumour dissemination and adversely affects survival after liver resection. British J Surg 2005;92:1165-1168.

74) Agarwal P, Seely J, Matzinger F, et al. Pleural mesothelioma: sensitivity and incidence of needle tract seeding after image-guided biopsy versus surgical biopsy. Radiology

2006;241:589-594. 
Tables

Table 1: Recommendations for bleeding risk evaluation and management $[7,8]$

\begin{tabular}{|c|c|c|c|}
\hline \multicolumn{4}{|c|}{ Risk of bleeding } \\
\hline & Low (category 1) & Moderate (category 2) & High (category 3) \\
\hline Type of PNB & $\begin{array}{l}\text { Superficial (thyroid, } \\
\text { lymph nodes) }\end{array}$ & $\begin{array}{l}\text { Lung, chest wall, } \\
\text { intraabdominal }\end{array}$ & Renal \\
\hline \multicolumn{4}{|c|}{ Laboratory tests } \\
\hline- INR & $\begin{array}{l}\text { Recommended for } \\
\text { patients receiving } \\
\text { warfarin or liver } \\
\text { disease }\end{array}$ & Recommended & $\begin{array}{l}\text { Routinely } \\
\text { recommended }\end{array}$ \\
\hline - aPTT & $\begin{array}{l}\text { Recommended for } \\
\text { patients receiving } \\
\text { intravenous } \\
\text { unfractioned heparin }\end{array}$ & $\begin{array}{c}\text { Recommended for } \\
\text { patients receiving } \\
\text { intravenous unfractioned } \\
\text { heparin }\end{array}$ & $\begin{array}{l}\text { Recommended for } \\
\text { patients receiving } \\
\text { intravenous } \\
\text { unfractioned heparin }\end{array}$ \\
\hline - Platelet count & $\begin{array}{l}\text { Not routinely } \\
\text { recommended }\end{array}$ & $\begin{array}{l}\text { Not routinely } \\
\text { recommended }\end{array}$ & $\begin{array}{l}\text { Routinely } \\
\text { recommended }\end{array}$ \\
\hline - Hematocrit & $\begin{array}{l}\text { Not routinely } \\
\text { recommended }\end{array}$ & $\begin{array}{l}\text { Not routinely } \\
\text { recommended }\end{array}$ & $\begin{array}{l}\text { Routinely } \\
\text { recommended }\end{array}$ \\
\hline \multicolumn{4}{|c|}{ Management } \\
\hline- INR & $\begin{array}{l}>2.0 \text { : threshold for } \\
\text { treatment }\end{array}$ & Correct to $<1.5$ & Correct to $<1.5$ \\
\hline - aPTT & No consensus & No consensus & $\begin{array}{l}\text { Stop or reverse } \\
\text { heparin for values } \\
>1.5 \times \text { control }\end{array}$ \\
\hline - Platelet count & $\begin{array}{c}\text { Transfusion for } \\
\text { counts }<50,000 / \mu \mathrm{L}\end{array}$ & $\begin{array}{c}\text { Transfusion for counts }< \\
50,000 / \mu \mathrm{L}\end{array}$ & $\begin{array}{c}\text { Transfusion for } \\
\text { counts }<50,000 / \mu \mathrm{L}\end{array}$ \\
\hline - Hematocrit & $\begin{array}{l}\text { No recommended } \\
\text { threshold for } \\
\text { transfusion }\end{array}$ & $\begin{array}{l}\text { No recommended } \\
\text { threshold for transfusion }\end{array}$ & $\begin{array}{l}\text { No recommended } \\
\text { threshold for } \\
\text { transfusion }\end{array}$ \\
\hline - Clopidrogrel & $\begin{array}{l}\text { Withhold for } 5 \text { days } \\
\text { before the procedure }\end{array}$ & $\begin{array}{l}\text { Withhold for } 5 \text { days } \\
\text { before the procedure }\end{array}$ & $\begin{array}{l}\text { Withhold for } 5 \text { days } \\
\text { before the procedure }\end{array}$ \\
\hline - Aspirin & Do not withhold & Do not withhold & $\begin{array}{l}\text { Withhold for } 5 \text { days } \\
\text { before the procedure }\end{array}$ \\
\hline - LMWH & $\begin{array}{l}\text { Withhold one dose } \\
\text { before the procedure }\end{array}$ & $\begin{array}{l}\text { Withhold one dose } \\
\text { before the procedure }\end{array}$ & $\begin{array}{l}\text { Withhold for } 24 \mathrm{~h} \text { or } \\
\text { up to two doses }\end{array}$ \\
\hline $\begin{array}{l}\text { - New oral } \\
\text { anticoagulants }\end{array}$ & Do not withhold & $\begin{array}{l}\text { Withhold for 2-3 days } \\
\text { before the procedure }\end{array}$ & $\begin{array}{l}\text { Withhold for } 3 \text { days } \\
\text { before the procedure }\end{array}$ \\
\hline
\end{tabular}

Legend:

INR: International Normalized Ratio

aPTT: activated partial thromboplastin time

LMWH: low molecular weight heparin 
Table 2: Imaging Techniques for PNB

\begin{tabular}{|c|c|c|c|c|}
\hline & Fluoroscopy & Ultrasound & $\begin{array}{l}\text { Computed } \\
\text { tomography }\end{array}$ & $\begin{array}{l}\text { Magnetic } \\
\text { Resonance }\end{array}$ \\
\hline $\begin{array}{l}\text { Real time } \\
\text { imaging }\end{array}$ & Yes & Yes & $\begin{array}{l}\text { Only for CT } \\
\text { fluoroscopy }\end{array}$ & $\begin{array}{c}\text { Near real time, } \\
\text { with specific } \\
\text { sequences }\end{array}$ \\
\hline Field of view & Limited & Limited & Large & Large \\
\hline $\begin{array}{l}\text { Visualization of } \\
\text { structures and } \\
\text { devices }\end{array}$ & $\begin{array}{c}\text { Poor } \\
\text { Usually } \\
\text { sufficient for } \\
\text { bone biopsy. } \\
\text { Multiplanar } \\
\text { visualization }\end{array}$ & $\begin{array}{l}\text { Limited in obese } \\
\text { patients and deep } \\
\text { lesions. } \\
\text { Possible } \\
\text { interference of } \\
\text { surrounding } \\
\text { structures }\end{array}$ & $\begin{array}{c}\text { Good } \\
\text { In specific } \\
\text { situations, contrast } \\
\text { media can be } \\
\text { injected to detect } \\
\text { lesion and vascular } \\
\text { structure }\end{array}$ & $\begin{array}{l}\text { Excellent } \\
\text { High contrast } \\
\text { resolution } \\
\text { Multiplanar and } \\
\text { tridimensional } \\
\text { visualization }\end{array}$ \\
\hline Portability & No & Yes & No & No \\
\hline Availability & ++ & +++ & ++ & + \\
\hline Ionizing radiation & Yes & Absent & Yes & Absent \\
\hline Procedural time & + & + & ++ & +++ \\
\hline Costs & ++ & + & ++ & +++ \\
\hline
\end{tabular}

Supplementary Tables: PNB procedural features and complications by anatomical regions (for Supplementary Tables please see the online version of "CIRSE Guidelines on Percutaneous Needle Biopsy (PNB)") 
APPENDIX (SIR classification of complications by outcome [3])

\section{Minor Complications}

a. No therapy, no consequence.

b. Nominal therapy, no consequence; includes overnight admission for observation only.

\section{Major Complications}

c. Require therapy, minor hospitalisation ( $<48$ hours).

d. Require major therapy, unplanned increase in level of care, prolonged hospitalisation ( $>48$ hours).

e. Permanent adverse.

f. Death. 
Supplementary Tables: PNB procedural features and complications by anatomical regions

Table 3: Head and neck

\begin{tabular}{|c|c|c|}
\hline \multicolumn{2}{|c|}{ Head and neck } & \multirow[b]{2}{*}{ Comments } \\
\hline & Pre-treatment Imaging & \\
\hline Main & $\begin{array}{l}\text { Ultrasound (Doppler color flow mapping) } \\
\text { Contrast-enhanced Computed Tomography (CT) } \\
\text { Magnetic Resonance }\end{array}$ & \\
\hline \multirow[t]{2}{*}{ Additional } & PET-CT & \\
\hline & Indications & \\
\hline Main & $\begin{array}{l}\text { Benign versus malignant } \\
\text { Inflammatory/infectious versus neoplastic } \\
\text { Neoplasm classification } \\
\text { Thyroid nodule category assessment } \\
\text { Primary vs. metastatic mass/lymphadenopathy }\end{array}$ & \\
\hline \multirow[t]{2}{*}{ Additional } & $\begin{array}{l}\text { Microbiological analysis } \\
\text { Immunohistochemistry }\end{array}$ & Multidisciplinary evaluation \\
\hline & Contraindications & \\
\hline Absolute & Patient refusal & \\
\hline \multirow[t]{2}{*}{ Relative } & Lymphoma classification (some histotypes) & \\
\hline & Patient Preparation & \\
\hline Main & $\begin{array}{l}\text { Outpatient } \\
2-4 \text { hours fasting } \\
\text { Patient positioning (based on anatomic and } \\
\text { technical considerations) }\end{array}$ & \\
\hline \multirow[t]{2}{*}{ Optional } & $\begin{array}{l}\text { INR, APTT, platelet count } \\
\text { Written informed consent for high risk patients }\end{array}$ & $\begin{array}{l}\text { Withhold Clopidogrel for } 5 \\
\text { days }\end{array}$ \\
\hline & Staffing issues & \\
\hline Required & $\begin{array}{l}\text { Interventional radiologist } \\
\text { Nurse } \\
\text { Pathologist on site } \\
\text { Anaesthesiologist on call }\end{array}$ & \\
\hline \multirow[t]{2}{*}{ Additional } & $\begin{array}{l}\text { Radiographer } \\
\text { Ear-Nose-Throat specialist on call }\end{array}$ & \\
\hline & Facility & \\
\hline Required & $\begin{array}{l}\text { Emergency resuscitation equipment (including } \\
\text { airways aspiration) }\end{array}$ & \\
\hline \multirow[t]{2}{*}{ Optional } & Facilities for on site cytopathology assessment & \\
\hline & Imaging guidance & \\
\hline Main & $\begin{array}{l}\text { Ultrasound } \\
\text { Computed Tomography }\end{array}$ & $\begin{array}{l}\text { Based on lesion location and } \\
\text { operator choice }\end{array}$ \\
\hline \multirow[t]{2}{*}{ Additional } & Magnetic Resonance & \\
\hline & Technique & \\
\hline Required & $\begin{array}{l}\text { Imaging localization of the access site } \\
\text { Skin disinfection } \\
\text { Fine-needle aspiration (FNA) biopsy } \\
\text { Extemporary smears evaluation }\end{array}$ & FNA needle: $22-19 G$ \\
\hline
\end{tabular}




\begin{tabular}{|c|c|c|}
\hline Optional & $\begin{array}{l}\text { Local anesthesia } \\
\text { Core Biopsy (Tru-Cut, Full-core) } \\
\text { Coaxial technique } \\
\text { Samples collection and formalin fixation }\end{array}$ & Core biopsy needle: $18-14 \mathrm{G}$ \\
\hline & Periprocedural Care & \\
\hline Required & No & \\
\hline \multirow[t]{2}{*}{ Additional } & $\begin{array}{l}\text { Management of coagulation status } \\
\text { Sedation } \\
\text { Pain control } \\
\text { Airways aspiration }\end{array}$ & $\begin{array}{l}\text { Management of } \\
\text { complications, if any }\end{array}$ \\
\hline & Effectiveness & \\
\hline Technical & $\begin{array}{l}\text { Adequacy of sample about } 90 \% \\
\text { Sensitivity for malignancy within } 85-90 \% \\
\text { Possible IHC }\end{array}$ & $\begin{array}{l}\text { Recommended quality } \\
\text { improvement threshold: } 75 \%\end{array}$ \\
\hline \multirow[t]{2}{*}{ Clinical } & Impact on decision making & Monitored by periodic audit \\
\hline & Complications & \\
\hline Major & $\leq 1 \%$ & $\begin{array}{l}\text { Recommended quality } \\
\text { improvement threshold: } 2 \%\end{array}$ \\
\hline Minor & $\begin{array}{l}\text { Pain } \\
\text { Vasovagal reaction } \\
\text { Minor infection } \\
\text { Minor bleeding }\end{array}$ & \\
\hline
\end{tabular}


Supplementary Tables: PNB procedural features and complications by anatomical regions

Table 4: Thorax

\begin{tabular}{|c|c|c|}
\hline & Pre-treatment Imaging & Comments \\
\hline Main & $\begin{array}{l}\text { Contrast-enhanced Computed tomography (CT) } \\
\text { PET-CT }\end{array}$ & \\
\hline \multirow[t]{2}{*}{ Additional } & $\begin{array}{l}\text { Magnetic Resonance Imaging (MRI) } \\
\text { Ultrasound (US) }\end{array}$ & \\
\hline & Indications & \\
\hline Main & $\begin{array}{l}\text { Microbiological analysis } \\
\text { Benign versus malignant } \\
\text { Malignancy classification } \\
\end{array}$ & Multidisciplinary evaluation \\
\hline \multirow[t]{2}{*}{ Additional } & $\begin{array}{l}\text { Primary versus metastatic } \\
\text { Immunohistochemistry } \\
\text { Molecular analysis }\end{array}$ & \\
\hline & Contraindications & \\
\hline Absolute & Severe respiratory failure & \\
\hline \multirow[t]{2}{*}{ Relative } & $\begin{array}{l}\text { Coagulopathy } \\
\text { Impaired respiratory function }\end{array}$ & \\
\hline & Patient Preparation & \\
\hline Main & $\begin{array}{l}\text { Outpatient } \\
\text { 4-6 hours fasting } \\
\text { Coagulation test (INR) } \\
\text { Informed consent (IC) } \\
\text { Patient positioning (based on target site, patient } \\
\text { compliance/discomfort, etc.) }\end{array}$ & $\begin{array}{l}\text { No day case procedure in high } \\
\text { risk patient } \\
\text { Correction of coagulopathy }\end{array}$ \\
\hline \multirow[t]{2}{*}{ Optional } & $\begin{array}{l}\text { Inpatient } \\
\text { APTT, platelet count } \\
\text { Respiratory function tests } \\
\text { Adapted IC form for high risk patients }\end{array}$ & \\
\hline & Staffing issues & \\
\hline Required & $\begin{array}{l}\text { Interventional radiologist } \\
\text { Radiographer } \\
\text { Nurse } \\
\text { Anaesthesiologist on call }\end{array}$ & \\
\hline \multirow[t]{2}{*}{ Additional } & $\begin{array}{l}\text { Pathologist on site } \\
\text { Thoracic surgeon on call }\end{array}$ & \\
\hline & Facility & \\
\hline Required & $\begin{array}{l}\text { Pulse oxymeter } \\
\text { Emergency resuscitation equipment } \\
\text { Equipment for decompression of tension } \\
\text { pneumothorax }\end{array}$ & \\
\hline \multirow[t]{2}{*}{ Optional } & Facilities for on site cytopathology assessment & \\
\hline & Imaging guidance & \\
\hline Main & $\begin{array}{l}\text { Computed Tomography } \\
\text { Ultrasound }\end{array}$ & $\begin{array}{l}\text { Based on lesion location and } \\
\text { size, and operator choice }\end{array}$ \\
\hline
\end{tabular}




\begin{tabular}{|c|c|c|}
\hline Additional & $\begin{array}{l}\text { Fluoroscopy } \\
\text { CT-fluoroscopy } \\
\text { Fusion imaging }\end{array}$ & $\begin{array}{l}\text { Navigation systems when } \\
\text { available and needed }\end{array}$ \\
\hline & Technique & \\
\hline Required & $\begin{array}{l}\text { Imaging localization of the access site } \\
\text { Skin disinfection and local anesthesia } \\
\text { Core biopsy (Tru-cut) } \\
\text { Fine-needle aspiration (FNA) } \\
\text { Samples collection and formalin fixation } \\
\text { Early low-dose CT (or chest radiograph) control } \\
\text { Chest radiograph after 2-4 hours }\end{array}$ & $\begin{array}{l}\text { Core biopsy needle: } 18-14 G \\
\text { FNA needle: } 22-19 G\end{array}$ \\
\hline \multirow[t]{2}{*}{ Optional } & $\begin{array}{l}\text { Coaxial technique } \\
\text { Spirotome needle } \\
\text { Extemporary touch imprints or smears evaluation }\end{array}$ & $\begin{array}{l}\text { Touch imprints or smears } \\
\text { evaluation when pathologists } \\
\text { or cytotechnologists on site }\end{array}$ \\
\hline & Periprocedural Care & \\
\hline Required & $\begin{array}{l}\mathrm{O}_{2} \text { saturation monitoring } \\
\text { Pulse and blood pressure monitoring }\end{array}$ & X-ray control after $2-4$ hours \\
\hline \multirow[t]{2}{*}{ Additional } & $\begin{array}{l}\text { Management of coagulation status } \\
\text { Sedation } \\
\mathrm{O}_{2} \text { administration } \\
\text { Pain control }\end{array}$ & $\begin{array}{l}\text { Management of complications, } \\
\text { if any }\end{array}$ \\
\hline & Effectiveness & \\
\hline Technical & $\begin{array}{l}\text { Adequacy of sample } \geq 90 \% \\
\text { Sensitivity for malignancy within } 85-90 \% \\
\text { Possible molecular profiling }\end{array}$ & $\begin{array}{l}\text { Recommended quality } \\
\text { improvement (QI) threshold: } \\
75 \%\end{array}$ \\
\hline \multirow[t]{2}{*}{ Clinical } & Impact on decision making & Monitored by periodic audit \\
\hline & Complications & \\
\hline Major & $\begin{array}{l}\text { Pneumothorax requiring tube placement and } \\
\text { prolonged admission } 1-3 \% \\
\text { Haemorrhage requiring hospitalization } 0.5 \% \\
\text { Air embolism } 0.06-0.07 \% \\
\text { Death }\end{array}$ & $\begin{array}{l}\text { Recommended QI threshold: } \\
-3 \% \\
-2 \% \\
-0.1 \%\end{array}$ \\
\hline Minor & $\begin{array}{l}\text { Pneumothorax } 12-45 \% \\
\text { Haemorrhage not requiring hospitalization }\end{array}$ & $\begin{array}{l}\text { Recommended QI threshold: } \\
45 \%\end{array}$ \\
\hline
\end{tabular}


Table 5: Liver

\begin{tabular}{|c|c|c|}
\hline \multicolumn{3}{|l|}{ Liver } \\
\hline & Pre-treatment Imaging & Comments \\
\hline Main & $\begin{array}{l}\text { Magnetic Resonance Imaging (MRI) with - } \\
\text { hepatocyte-specific- contrast agents } \\
\text { Ultrasound (US) or CEUS } \\
\text { Contrast-enhanced Computed Tomography (CT) }\end{array}$ & $\begin{array}{l}\text { MRI can eliminate the need for } \\
\text { lesion biopsy }\end{array}$ \\
\hline \multirow[t]{2}{*}{ Additional } & PET-CT & \\
\hline & Indications & \\
\hline Main & $\begin{array}{l}\text { Non-targeted } \\
\text { Targeted }\end{array}$ & $\begin{array}{l}\text { Diagnosis, prognosis, staging, } \\
\text { treatment planning, and } \\
\text { assessing response to } \\
\text { treatment of diffuse } \\
\text { parenchymal liver disease. } \\
\text { Diagnosis of lesions deemed } \\
\text { indeterminate on imaging } \\
\text { studies. } \\
\text { If required, thrombus within } \\
\text { the portal vein itself can be } \\
\text { biopsied to determine } \\
\text { whether clot is bland or } \\
\text { malignant. }\end{array}$ \\
\hline \multirow[t]{2}{*}{ Additional } & $\begin{array}{l}\text { Benign versus malign } \\
\text { Primary versus metastatic } \\
\text { Stage malignancy } \\
\text { Immunohistochemistry } \\
\text { Molecular analysis } \\
\text { Microbiological analysis }\end{array}$ & $\begin{array}{l}\text { In neutropenic patients, fungal } \\
\text { abscesses or neoplasia }\end{array}$ \\
\hline & Contraindications & \\
\hline Absolute & $\begin{array}{l}\text { Uncorrected coagulopathies } \\
\text { History of unexplained bleeding } \\
\text { Unavailability of blood transfusion support } \\
\text { Recent use of aspirin or other antiplatelet drugs } \\
\text { (within last 5-7 days) } \\
\text { Cardiopulmonary or hemodynamic instability } \\
\text { Lack of safe access to lesion }\end{array}$ & Transjugular liver biopsy \\
\hline Relative & $\begin{array}{l}\text { Uncooperative patient } \\
\text { Ascites } \\
\text { Morbid obesity } \\
\text { Infection in the right pleural cavity or below the } \\
\text { right hemi-diaphragm } \\
\text { Suspected hemangioma or other vascular tumor } \\
\text { Hydatid disease } \\
\text { Hemophilia }\end{array}$ & $\begin{array}{l}\text { Transjugular liver biopsy } \\
\text { Paracentesis should be } \\
\text { considered prior to biopsy. }\end{array}$ \\
\hline
\end{tabular}




\begin{tabular}{|c|c|c|}
\hline & $\begin{array}{l}\text { Extrahepatic biliary obstruction } \\
\text { Bacterial cholangitis } \\
\text { History of biliary-enteric anastomosis }\end{array}$ & \\
\hline & Patient Preparation & \\
\hline Main & $\begin{array}{l}\text { Outpatient } \\
\text { 4-6 hour fasting } \\
\text { Coagulation test PT, PTT, INR, and platelet count } \\
\text { Correction of coagulopathy } \\
\text { Informed consent (IC) } \\
\text { Patient positioning (based on target site, patient } \\
\text { compliance/discomfort, etc.) }\end{array}$ & $\begin{array}{l}\text { An International normalized } \\
\text { ratio (INR) no greater than } 1.5 \\
\text { Platelet count greater than } \\
50,000 / \mu \mathrm{L} \\
\text { Antiplatelet medications such } \\
\text { as aspirin and Plavix should be } \\
\text { discontinued } 5-7 \text { days prior to } \\
\text { the procedure. }\end{array}$ \\
\hline \multirow[t]{2}{*}{ Optional } & $\begin{array}{l}\text { Inpatient } \\
\text { Adapted IC form for high risk patients } \\
\text { Alpha-fetal protein for HCC } \\
\text { Echinococcal serology }\end{array}$ & $\begin{array}{l}\text { No day case procedure in high } \\
\text { risk patient } \\
\text { Consultation with the patient's } \\
\text { cardiologist if necessary. }\end{array}$ \\
\hline & Staffing issues & \\
\hline Required & $\begin{array}{l}\text { Interventional radiologist } \\
\text { Nurse } \\
\text { Radiographer }\end{array}$ & Not in case of US-guidance \\
\hline \multirow[t]{2}{*}{ Additional } & $\begin{array}{l}\text { Anaesthesiologist for sedation } \\
\text { Pathologist on site } \\
\text { Vascular interventional radiologist on call }\end{array}$ & \\
\hline & Facility & \\
\hline Required & $\begin{array}{l}\text { Pulse oxymeter } \\
\text { Emergency resuscitation equipment }\end{array}$ & \\
\hline \multirow[t]{2}{*}{ Optional } & $\begin{array}{l}\text { Equipment for decompression of tension } \\
\text { pneumothorax } \\
\text { Facilities for onsite cytopathology assessment }\end{array}$ & \\
\hline & Imaging guidance & \\
\hline Main & $\begin{array}{l}\text { US (including color-Doppler) } \\
\text { CT }\end{array}$ & $\begin{array}{l}\text { Ultrasound is the preferred } \\
\text { imaging modality. } \\
\mathrm{CT} \text { is usually reserved for } \\
\text { lesions not sufficiently visible } \\
\text { with ultrasound. } \\
\mathrm{CT} \text { is not used for non-targeted } \\
\text { liver biopsy. }\end{array}$ \\
\hline \multirow[t]{2}{*}{ Additional } & $\begin{array}{l}\text { MRI } \\
\text { CT-fluoroscopy } \\
\text { Fusion imaging } \\
\text { PET-CT }\end{array}$ & $\begin{array}{l}\text { Navigation system when } \\
\text { needed and available }\end{array}$ \\
\hline & Technique & \\
\hline Required & $\begin{array}{l}\text { Skin disinfection and local anesthesia } \\
\text { Core biopsy (Tru-Cut): } 16-20 \mathrm{G} \\
\text { Fine-needle aspiration (FNA): } 20-25 \mathrm{G} \\
\text { Samples collection and formalin fixation }\end{array}$ & $\begin{array}{l}\text { If the subcostal window is } \\
\text { available, it should be first } \\
\text { preference. } \\
\text { Avoid the aerated lung and } \\
\text { gallbladder during intercostal } \\
\text { puncture. }\end{array}$ \\
\hline
\end{tabular}




\begin{tabular}{|c|c|c|}
\hline & & $\begin{array}{l}\text { The sub-xiphoid approach is } \\
\text { best for targeting the left } \\
\text { hepatic lobe. } \\
\text { Visible, and especially central, } \\
\text { branches of the hepatic artery } \\
\text { should always be avoided. }\end{array}$ \\
\hline \multirow[t]{2}{*}{ Optional } & $\begin{array}{l}\text { Sedation } \\
\text { Coaxial technique } \\
\text { Tract embolization }\end{array}$ & $\begin{array}{l}\text { Biopsy track can be occluded } \\
\text { using a hemostatic substance } \\
\text { such as gelatin foam, which } \\
\text { may minimize the risks of } \\
\text { tumor seeding and bleeding. }\end{array}$ \\
\hline & Periprocedural Care & \\
\hline Required & $\begin{array}{l}\mathrm{O}_{2} \text { saturation monitoring } \\
\text { Pulse and blood pressure monitoring } \\
\text { 4-6 hours observation after the procedure }\end{array}$ & $\begin{array}{l}\text { Most major complications are } \\
\text { clinically evident within } 2 \\
\text { hours post procedure }\end{array}$ \\
\hline \multirow[t]{2}{*}{ Additional } & $\begin{array}{l}\text { Sedation (especially in children) } \\
\text { Postoperative pain control }\end{array}$ & Management of complications \\
\hline & Effectiveness & \\
\hline Technical & $\begin{array}{l}\text { Adequacy of sample } \geq 90 \% \\
\text { Overall sensitivity and specificity for a focal lesion } \\
\text { of } 96.4 \% \text { and } 96.7 \% \text { respectively, with diagnostic } \\
\text { accuracy of } 96.4 \% \text {. } \\
\text { Overall, diagnostic sensitivity about } 98 \% \text { for } \\
\text { metastases and } 87 \% \text { for HCC. }\end{array}$ & $\begin{array}{l}\text { Recommended quality } \\
\text { improvement (QI) threshold: } \\
75 \%\end{array}$ \\
\hline \multirow[t]{2}{*}{ Clinical } & Biopsy outcome relevant for management & Monitored by periodic audit \\
\hline & Complications & \\
\hline Major & $\begin{array}{l}\text {-Vascular (<1\%) } \\
\text { Hemorrhage requiring transfusion or other } \\
\text { intervention (<1\%) } \\
\text { Arteriovenous fistula / pseudoaneuriysm } \\
\text { Hemobilia } \\
\frac{\text {-Infectious }(<1 \%)}{\text { Liver abscess }} \\
\text { Cholangitis } \\
\text { Bacteriemia /sepsis } \\
\text {-Injury of surrounding structures } \\
\text { Pneumothorax / pleural effusion }(<1 \%) \\
\text { Bile leakage and peritonitis (<1\%) } \\
\text { Gallbladder or bowel perforation }(<1 \%) \\
\text { Malignant tract seeding }(<1 \%) \\
\text { Death (0\% to } 0.5 \%)\end{array}$ & $\begin{array}{l}\text { Recommended quality } \\
\text { improvement (QI) threshold: } \\
-5 \%\end{array}$ \\
\hline Minor & $\begin{array}{l}\text { Hemorrhage not requiring intervention }(<1 \%) \\
\text { Pain (up to } 84 \% \text { ) }\end{array}$ & \\
\hline
\end{tabular}


Supplementary Tables: PNB procedural features and complications by anatomical regions

Table 6: Abdominal mass (excluding liver and retroperitoneum)

\section{Abdominal mass (excluding liver and retroperitoneum)}

\begin{tabular}{|c|c|c|}
\hline & Pre-treatment Imaging & Comments \\
\hline Main & $\begin{array}{l}\text { Contrast-enhanced Computed Tomography (CT) } \\
\text { Magnetic Resonance Imaging (MRI) }\end{array}$ & \\
\hline \multirow[t]{2}{*}{ Additional } & $\begin{array}{l}\text { Ultrasound (US) } \\
\text { PET-CT }\end{array}$ & \\
\hline & Indications & \\
\hline Main & $\begin{array}{l}\text { Inflammatory/infectious versus neoplastic } \\
\text { Benign versus malignant } \\
\text { Neoplasms classification } \\
\text { Primary versus metastatic }\end{array}$ & \\
\hline \multirow[t]{2}{*}{ Additional } & $\begin{array}{l}\text { Immunohistochemistry (IHC) } \\
\text { Molecular analysis }\end{array}$ & \\
\hline & Contraindications & \\
\hline Absolute & Uncorrectable coagulopathy & Mainly for spleen biopsy \\
\hline \multirow[t]{2}{*}{ Relative } & $\begin{array}{l}\text { More likely gastro-intestinal origin } \\
\text { Need of transperitoneal route for operable } \\
\text { suspected malignancy } \\
\text { Adjustable coagulopathy }\end{array}$ & Prefer endoscopic biopsy \\
\hline & Patient Preparation & \\
\hline Main & $\begin{array}{l}\text { Day case procedure } \\
\text { 4-6 hours fasting } \\
\text { Coagulation test (INR, APTT, platelet count) } \\
\text { Informed consent (IC) } \\
\text { Patient positioning (based on target site, patient } \\
\text { compliance/discomfort, etc.) }\end{array}$ & $\begin{array}{l}\text { Correction of coagulopathy, } \\
\text { withhold Clopidogrel and/or } \\
\text { Aspirin: for } 5 \text { days }\end{array}$ \\
\hline \multirow[t]{2}{*}{ Optional } & $\begin{array}{l}\text { Inpatient } \\
\text { Adapted IC form for high risk patients }\end{array}$ & High risk patients \\
\hline & Staffing issues & \\
\hline Required & $\begin{array}{l}\text { Interventional radiologist } \\
\text { Nurse } \\
\text { Pathologist on site } \\
\text { Anaesthesiologist on call }\end{array}$ & \\
\hline \multirow[t]{2}{*}{ Additional } & Radiographer & In case of CT/MR guidance \\
\hline & Facility & \\
\hline Required & $\begin{array}{l}\text { Emergency resuscitation equipment } \\
\text { Facilities for on site cytopathology assessment }\end{array}$ & \\
\hline \multirow[t]{2}{*}{ Optional } & Pulse and blood pressure monitoring & \\
\hline & Imaging guidance & \\
\hline Main & $\begin{array}{l}\text { US (including color-Doppler) } \\
\text { CT }\end{array}$ & $\begin{array}{l}\text { Based on lesion location and } \\
\text { operator choice }\end{array}$ \\
\hline Additional & $\begin{array}{l}\text { MRI } \\
\text { Contrast Enhanced US } \\
\text { CT-fluoroscopy or Cone Beam-CT }\end{array}$ & $\begin{array}{l}\text { Navigation systems when } \\
\text { available and needed }\end{array}$ \\
\hline
\end{tabular}




\begin{tabular}{|c|c|c|}
\hline & Fusion imaging & \\
\hline & Technique & \\
\hline Required & $\begin{array}{l}\text { Imaging localization of the access site } \\
\text { Skin disinfection and local anesthesia } \\
\text { Fine-needle aspiration (FNA) } \\
\text { Extemporary smears evaluation } \\
\text { Samples collection and formalin fixation } \\
\text { US or CT post-procedural control } \\
\text { Blood count after } 2 \text { hours }\end{array}$ & FNA needle: $22-19 G$ \\
\hline \multirow[t]{2}{*}{ Optional } & $\begin{array}{l}\text { Core biopsy (Tru-cut, full-core) } \\
\text { Coaxial technique } \\
\text { Organ displacement techniques } \\
\text { Trans-organ/visceral approach }\end{array}$ & Core biopsy needle: $18-14 \mathrm{G}$ \\
\hline & Periprocedural Care & \\
\hline Required & No & \\
\hline \multirow[t]{2}{*}{ Additional } & $\begin{array}{l}\text { Management of coagulation status } \\
\text { Sedation } \\
\text { Pulse and blood pressure monitoring } \\
\text { Pain control }\end{array}$ & $\begin{array}{l}\text { Management of } \\
\text { complications, if any }\end{array}$ \\
\hline & Effectiveness & \\
\hline Technical & $\begin{array}{l}\text { Adequacy of sample } \geq 90 \% \\
\text { Sensitivity for malignancy within } 85-90 \% \\
\text { Possible IHC and molecular analysis }\end{array}$ & $\begin{array}{l}\text { Recommended quality } \\
\text { improvement (QI) threshold: } \\
75 \%\end{array}$ \\
\hline \multirow[t]{2}{*}{ Clinical } & Impact on decision making & Monitored by periodic audit \\
\hline & Complications & \\
\hline Major & $\begin{array}{l}\text { Bleeding requiring transfusion or intervention: } \\
\text { - Spleen } 0-8.3 \% \\
\text { - Other } 0.1-3 \% \\
\text { Tract seeding: } 0.3-4 \% \\
\text { Pneumothorax requiring chest tube placement: } \\
0.5 \% \\
\text { Death }\end{array}$ & $\begin{array}{l}\text { Recommended QI threshold: } \\
-10 \% \\
-6 \% \\
-5 \% \\
-1 \%\end{array}$ \\
\hline Minor & $\begin{array}{l}\text { Bleeding not requiring transfusion or } \\
\text { intervention } \\
\text { Pneumothorax not requiring chest tube } \\
\text { placement } \\
\text { Vasovagal reaction } \\
\text { Pain }\end{array}$ & \\
\hline
\end{tabular}


Supplementary Tables: PNB procedural features and complications by anatomical regions

Table 7: Retroperitoneum

\begin{tabular}{|c|c|c|}
\hline \multirow{2}{*}{ Retroperitoneum } & \multicolumn{2}{|c|}{ 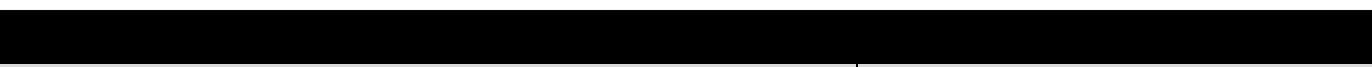 } \\
\hline & Classification of tumors by origin & Comments \\
\hline $\begin{array}{l}\text { Arising from major } \\
\text { solid organs } \\
\text { (common) }\end{array}$ & $\begin{array}{l}\text { Pancreas } \\
\text { Kidney } \\
\text { Adrenal gland }\end{array}$ & \\
\hline \multirow[t]{2}{*}{$\begin{array}{l}\text { Primary } \\
\text { (uncommon) }\end{array}$} & $\begin{array}{l}\text { Malignant } \\
\text { Benign }\end{array}$ & $70-80 \%$, mostly sarcomas \\
\hline & Pre-treatment Imaging & Comments \\
\hline Main & $\begin{array}{l}\text { Contrast-enhanced Computed Tomography (CT) } \\
\text { Magnetic Resonance Imaging (MRI) }\end{array}$ & \\
\hline \multirow[t]{2}{*}{ Additional } & $\begin{array}{l}\text { Ultrasound (US) } \\
\text { PET-CT }\end{array}$ & \\
\hline & Indications & \\
\hline Main & $\begin{array}{l}\text { Benign versus malignant } \\
\text { Malignancy classification } \\
\text { Primary versus metastatic }\end{array}$ & \\
\hline \multirow[t]{2}{*}{ Additional } & $\begin{array}{l}\text { Infectious versus neoplastic } \\
\text { Immunohistochemistry }\end{array}$ & Multidisciplinary evaluation \\
\hline & Contraindications & \\
\hline Absolute & $\begin{array}{l}\text { Lesions non attainable without crossing vital } \\
\text { organs }\end{array}$ & \\
\hline \multirow[t]{2}{*}{ Relative } & $\begin{array}{l}\text { Need of transperitoneal route for operable } \\
\text { tumors } \\
\text { Coagulopathy }\end{array}$ & $\begin{array}{l}\text { Prefer Endoscopic US-guided } \\
\text { biopsy }\end{array}$ \\
\hline & Patient Preparation & \\
\hline Main & $\begin{array}{l}\text { Day case procedure } \\
\text { 4-6 hours fasting } \\
\text { Coagulation test (INR) } \\
\text { Informed consent (IC) } \\
\text { Patient positioning (based on target site, patient } \\
\text { compliance/discomfort, etc.) }\end{array}$ & $\begin{array}{l}\text { Correction of coagulopathy } \\
\text { Prone position preferred }\end{array}$ \\
\hline \multirow[t]{2}{*}{ Optional } & $\begin{array}{l}\text { Inpatient } \\
\text { APTT, platelet count } \\
\text { Adrenal function tests } \\
\text { Adapted IC form for high risk patients }\end{array}$ & $\begin{array}{l}\text { Withhold Aspirin for } 5 \text { days } \\
\text { Acute hypertension } \\
\text { prevention }\end{array}$ \\
\hline & Staffing issues & \\
\hline Required & $\begin{array}{l}\text { Interventional radiologist } \\
\text { Radiographer } \\
\text { Nurse } \\
\text { Anaesthesiologist on call }\end{array}$ & \\
\hline \multirow[t]{2}{*}{ Additional } & Pathologist on site & \\
\hline & Facility & \\
\hline Required & $\begin{array}{l}\text { Pulse and blood pressure monitoring Emergency } \\
\text { resuscitation equipment }\end{array}$ & \\
\hline
\end{tabular}




\begin{tabular}{|c|c|c|}
\hline \multirow[t]{2}{*}{ Optional } & Facilities for on site cytopathology assessment & \\
\hline & \multicolumn{2}{|l|}{ Imaging guidance } \\
\hline Main & $\begin{array}{l}\text { CT } \\
\text { US }\end{array}$ & $\begin{array}{l}\text { Based on lesion location and } \\
\text { operator choice }\end{array}$ \\
\hline \multirow[t]{2}{*}{ Additional } & $\begin{array}{l}\text { MRI } \\
\text { Contrast Enhanced US } \\
\text { CT-fluoroscopy or Cone Beam-CT }\end{array}$ & \\
\hline & Technique & \\
\hline Required & $\begin{array}{l}\text { Imaging localization of the access site } \\
\text { Skin disinfection and local anesthesia } \\
\text { Fine-needle aspiration } \\
\text { Core biopsy (Tru-cut) } \\
\text { Samples collection and formalin fixation } \\
\text { CT (or other imaging modalities) post- } \\
\text { procedural control }\end{array}$ & $\begin{array}{l}\text { FNA needle: } 22-19 G \\
\text { Core biopsy needle: } 18-14 G\end{array}$ \\
\hline \multirow[t]{2}{*}{ Optional } & $\begin{array}{l}\text { Coaxial technique } \\
\text { Transhepatic approach } \\
\text { Extemporary smears or touch imprints } \\
\text { evaluation }\end{array}$ & $\begin{array}{l}\text { Mandatory for renal biopsy } \\
\text { Right renal or adrenal biopsy } \\
\text { Smears evaluation when } \\
\text { pathologists on site }\end{array}$ \\
\hline & Periprocedural Care & \\
\hline Required & Pulse and blood pressure monitoring & \\
\hline \multirow[t]{2}{*}{ Additional } & $\begin{array}{l}\text { Management of coagulation status } \\
\text { Sedation } \\
\text { Pain control } \\
\text { Prevention of hypertension }\end{array}$ & $\begin{array}{l}\text { Management of } \\
\text { complications, if any }\end{array}$ \\
\hline & Effectiveness & \\
\hline Technical & $\begin{array}{l}\text { Adequacy of sample } \geq 90 \% \\
\text { Sensitivity for malignancy within } 85-90 \% \\
\text { Possible immunohistochemistry }\end{array}$ & $\begin{array}{l}\text { Recommended quality } \\
\text { improvement threshold: } 75 \%\end{array}$ \\
\hline \multirow[t]{2}{*}{ Clinical } & Impact on decision making & Monitored by periodic audit \\
\hline & Complications & \\
\hline Major & $\begin{array}{l}\text { Bleeding requiring transfusion or intervention: } \\
\text { - Kidney: } 2.7-6.6 \% \\
\text { - Other: } 0.1-3 \% \\
\text { Pancreatitis } \\
\text { Hypertensive crisis } \\
\text { Pneumothorax/hemothorax requiring chest } \\
\text { tube placement } \\
\text { Tract seeding: } 0.3-4 \% \\
\text { Death }\end{array}$ & $\begin{array}{l}\text { Recommended QI threshold: } \\
-10 \% \\
-6 \% \\
-1 \% \\
-5 \%\end{array}$ \\
\hline Minor & $\begin{array}{l}\text { Overall 3-4\%, including: } \\
\text { Hematoma/hematuria not requiring } \\
\text { hospitalization } \\
\text { Lumbar pain } \\
\text { Hypertensive episodes } \\
\text { Thoracic complications not requiring drainage }\end{array}$ & \\
\hline
\end{tabular}


Supplementary Tables: PNB procedural features and complications by anatomical regions

Table 8: Prostate

\begin{tabular}{|c|c|c|}
\hline & Pre-treatment Imaging & Comments \\
\hline Main & $\begin{array}{l}\text { Trans-Rectal Ultrasound (Color-Doppler flow } \\
\text { mapping) }\end{array}$ & \\
\hline \multirow[t]{2}{*}{ Additional } & $\begin{array}{l}\text { Magnetic Resonance Imaging (MRI) } \\
\text { Contrast-enhanced Computed Tomography (CT) } \\
\text { PET-CT }\end{array}$ & \\
\hline & Indications & \\
\hline Main & $\begin{array}{l}\text { Benign versus malignant } \\
\text { Malignancy classification } \\
\text { Gleason Score assignment }\end{array}$ & Based on PSA and DRE results \\
\hline \multirow[t]{2}{*}{ Additional } & $\begin{array}{l}\text { Repeat biopsy } \\
\text { Immunohistochemistry }\end{array}$ & $\begin{array}{l}\text { Additional Transitional Zone } \\
\text { (TZ) biopsies }\end{array}$ \\
\hline & Contraindications & \\
\hline Absolute & Previous rectal amputation & \\
\hline \multirow[t]{2}{*}{ Relative } & $\begin{array}{l}\text { Coagulopathy } \\
\text { Anxiety-related anal sphincter spasm }\end{array}$ & \\
\hline & Patient Preparation & \\
\hline Main & $\begin{array}{l}\text { Outpatient } \\
4-6 \text { hours fasting } \\
\text { Coagulation test (INR) } \\
\text { Informed consent (IC) } \\
\text { Patient positioning (lateral left decubitus, etc.) }\end{array}$ & $\begin{array}{l}\text { No day case procedure in high } \\
\text { risk patient } \\
\text { Correction of coagulopathy }\end{array}$ \\
\hline \multirow[t]{2}{*}{ Optional } & $\begin{array}{l}\text { Inpatient (if admitted for other pathological } \\
\text { condition) } \\
\text { APTT, platelet count }\end{array}$ & \\
\hline & Staffing issues & \\
\hline Required & $\begin{array}{l}\text { Interventional radiologist } \\
\text { Nurse }\end{array}$ & \\
\hline \multirow[t]{2}{*}{ Additional } & $\begin{array}{l}\text { Radiographer } \\
\text { Pathologist on site }\end{array}$ & \\
\hline & Facility & \\
\hline Required & Emergency resuscitation equipment & \\
\hline \multirow[t]{2}{*}{ Optional } & Facilities for on site cytopathology assessment & Unusual \\
\hline & Imaging guidance & \\
\hline Main & Trans-Rectal US (color-Doppler) & Adapter as an option \\
\hline \multirow[t]{2}{*}{ Additional } & $\begin{array}{l}\text { MRI } \\
\text { Fusion imaging (MRI, rarely PET-CT, with TRUS) }\end{array}$ & When needed and available \\
\hline & Technique & \\
\hline Required & $\begin{array}{l}\text { Imaging localization of the biopsy route } \\
\text { (transperineal or transrectal) } \\
\text { Local anesthesia (plexus near the SV's junction on } \\
\text { both sides at the base, } 5 c c \text { of } 2 \% \text { lidocaine in each } \\
\text { side) }\end{array}$ & $\begin{array}{l}\text { Core biopsy needle: } 18 \mathrm{G}, 20- \\
25 \mathrm{~cm} \text {, depending on guidance } \\
\text { probe } \\
8 \text { to } 12 \text { cores (from the base, }\end{array}$ \\
\hline
\end{tabular}




\begin{tabular}{|c|c|c|}
\hline & $\begin{array}{l}\text { Core biopsy (Tru-cut) } \\
\text { Samples collection and formalin fixation }\end{array}$ & $\begin{array}{l}\text { mid and apex), saturation (>20 } \\
\text { cores, including from TZ) in } \\
\text { case of repeat biopsy }\end{array}$ \\
\hline \multirow[t]{2}{*}{ Optional } & $\begin{array}{l}\text { Fragments of each collected sample in separated } \\
\text { location identified formalin recipient }\end{array}$ & If required by the Urologist \\
\hline & Periprocedural Care & \\
\hline Required & $\begin{array}{l}\text { Cleansing enema } \\
\text { Sedation (anxiolytic) } \\
\text { Prophylactic antibiotic intake }\end{array}$ & Quinolones (oral or iv) \\
\hline \multirow[t]{2}{*}{ Additional } & $\begin{array}{l}\text { Management of coagulation status } \\
\text { Pain control }\end{array}$ & $\begin{array}{l}\text { Management of complications, } \\
\text { if any }\end{array}$ \\
\hline & Effectiveness & \\
\hline Technical & $\begin{array}{l}\text { Adequacy of sample } \geq 90 \% \\
\text { Sensitivity for malignancy within } 85-90 \%\end{array}$ & $\begin{array}{l}\text { Recommended Quality } \\
\text { Improvement threshold: 75\% }\end{array}$ \\
\hline \multirow[t]{2}{*}{ Clinical } & Impact on decision making & Monitored by periodic audit \\
\hline & Complications & \\
\hline Major & Haemorrhage requiring hospitalization: $0.01 \%$ & $\begin{array}{l}\text { Recommended Quality } \\
\text { Improvement threshold: } 1 \%\end{array}$ \\
\hline Minor & Haemorrhage not requiring hospitalization: $2.15 \%$ & $\begin{array}{l}\text { Recommended Quality } \\
\text { Improvement threshold: } 6.1 \%\end{array}$ \\
\hline
\end{tabular}


Supplementary Tables: PNB procedural features and complications by anatomical regions

Table 9: Lymph node

\begin{tabular}{|c|c|c|}
\hline \multicolumn{2}{|c|}{ Lymph node } & \\
\hline & Pre-treatment Imaging & Comments \\
\hline Main & $\begin{array}{l}\text { Ultrasound (US) } \\
\text { Contrast-enhanced Computed tomography (CT) }\end{array}$ & $\begin{array}{l}\text { Superficial } \\
\text { Deep }\end{array}$ \\
\hline Additional & $\begin{array}{l}\text { Magnetic Resonance Imaging (MRI) } \\
\text { PET-CT }\end{array}$ & \\
\hline & Indications & \\
\hline Main & $\begin{array}{l}\text { Inflammatory/infectious versus neoplastic } \\
\text { Benign versus malignant } \\
\text { Primary versus metastatic } \\
\text { Stage malignancy } \\
\text { Sub-classification of lymphoma }\end{array}$ & \\
\hline Additional & $\begin{array}{l}\text { Microbiological analysis } \\
\text { Immunohistochemistry } \\
\text { Molecular analysis } \\
\text { Residual or recurrent disease following treatment }\end{array}$ & \\
\hline & Contraindications & \\
\hline Absolute & $\begin{array}{l}\text { Lack of safe access route to lesion } \\
\text { Cardiopulmonary or hemodynamic instability }\end{array}$ & Deep lymph node \\
\hline Relative & $\begin{array}{l}\text { Coagulopathy } \\
\text { Uncooperative patient } \\
\text { Suspected hemangioma or other vascular tumor } \\
\text { Hemophilia }\end{array}$ & \\
\hline & Patient Preparation & \\
\hline Main & $\begin{array}{l}\text { Outpatient } \\
\text { Deep lymph node: } \\
\text { - 4-6 hour fasting } \\
\text { - Coagulation tests (PT, PTT, INR) and platelet } \\
\text { count } \\
\text { Informed consent (IC) } \\
\text { Patient positioning (based on target site, patient } \\
\text { compliance/discomfort, etc.) }\end{array}$ & $\begin{array}{l}\text { Correction of coagulopathy for } \\
\text { deep lymph node: } \\
\text {-International normalized ratio } \\
\text { (INR) no greater than } 1.5 \\
\text {-Platelet count greater than } \\
50,000 / \mu L \\
\text {-Antiplatelet medications such } \\
\text { as aspirin and Clopidogrel } \\
\text { discontinued 5-7 days prior to } \\
\text { the procedure. }\end{array}$ \\
\hline Optional & $\begin{array}{l}\text { Inpatient } \\
\text { Adapted IC form for high risk patients }\end{array}$ & $\begin{array}{l}\text { No day case procedure in high } \\
\text { risk patient }\end{array}$ \\
\hline & Staffing issues & \\
\hline Required & $\begin{array}{l}\text { Interventional radiologist } \\
\text { Nurse } \\
\text { Radiographer }\end{array}$ & Not in case of US-guidance \\
\hline Additional & $\begin{array}{l}\text { Anaesthesiologist for sedation } \\
\text { Pathologist on site }\end{array}$ & \\
\hline & Facility & \\
\hline Required & Pulse oxymeter & \\
\hline
\end{tabular}




\begin{tabular}{|c|c|c|}
\hline & Emergency resuscitation equipment & \\
\hline \multirow[t]{2}{*}{ Optional } & Facilities for on site cytopathology assessment & \\
\hline & Imaging guidance & \\
\hline Main & $\begin{array}{l}\text { US } \\
\text { CT }\end{array}$ & $\begin{array}{l}\text { Based on lesion location and } \\
\text { operator choice }\end{array}$ \\
\hline \multirow[t]{2}{*}{ Additional } & $\begin{array}{l}\text { CT-fluoroscopy } \\
\text { MRI } \\
\text { Fusion imaging (US + PET-CT or others) }\end{array}$ & $\begin{array}{l}\text { Navigation systems when } \\
\text { available and needed }\end{array}$ \\
\hline & Technique & \\
\hline Required & $\begin{array}{l}\text { Skin disinfection and local anesthesia } \\
\text { Core biopsy (Tru-cut, full-core): } 14-20 \text { G } \\
\text { Fine-needle aspiration (FNA): } 20-25 G \\
\text { Samples collection and formalin fixation }\end{array}$ & $\begin{array}{l}\text { Core needle biopsies are } \\
\text { superior to FNA biopsies for } \\
\text { diagnosing lymphomas }\end{array}$ \\
\hline \multirow[t]{2}{*}{ Optional } & $\begin{array}{l}\text { Sedation } \\
\text { Coaxial technique } \\
\text { Organ-displacement techniques } \\
\text { - Hydrodissection; gas-dissection } \\
\text { Use of a curved needle } \\
\text { Gantry angulation } \\
\text { Trans-organ approaches (trans-hepatic, trans- } \\
\text { gastric, trans-renal, trans-splenic, trans-psoas, } \\
\text { trans-rectal, trans-vaginal, trans-gluteal, trans- } \\
\text { pleural and trans-pulmonary) } \\
\text { Needle tract embolization } \\
\text { Extemporary cytological evaluation } \\
\text { Flow cytometry }\end{array}$ & $\begin{array}{l}\text { The liver, spleen, stomach and } \\
\text { kidneys can be traversed } \\
(<18 \mathrm{G}) \\
\text { Transgressing the small or } \\
\text { large bowel with fine needles } \\
\text { is usually safe }(<20 \mathrm{G})\end{array}$ \\
\hline & Periprocedural Care & \\
\hline Required & $\begin{array}{l}\mathrm{O}_{2} \text { saturation monitoring } \\
\text { Pulse and blood pressure monitoring } \\
4-6 \text { hours observation after the procedure }\end{array}$ & $\begin{array}{l}\text { Deep lymph node } \\
\text { Most major complications are } \\
\text { clinically evident within } 2 \\
\text { hours post procedure }\end{array}$ \\
\hline \multirow[t]{2}{*}{ Additional } & $\begin{array}{l}\text { Sedation (especially in children) } \\
\text { Pain control }\end{array}$ & $\begin{array}{l}\text { Management of complications, } \\
\text { if any }\end{array}$ \\
\hline & Effectiveness & \\
\hline Technical & $\begin{array}{l}\text { Adequacy of sample } \geq 90 \% \\
\text { Overall sensitivity and specificity }>85 \%\end{array}$ & $\begin{array}{l}\text { Recommended quality } \\
\text { improvement (QI) threshold: } \\
75 \%\end{array}$ \\
\hline \multirow[t]{2}{*}{ Clinical } & Impact on decision making & Monitored by periodic audit \\
\hline & Complications & \\
\hline Major & $\begin{array}{l}\text {-Vascular }(<1 \%) \\
\text { Hemorrhage requiring transfusion or other } \\
\text { intervention }(<1 \%) \\
\text { Arteriovenous fistula /pseudoaneuriysm } \\
\text {-Infectious }(<1 \%) \\
\text { Abscess } \\
\text { Bacteriemia /sepsis } \\
\text {-Injury of surrounding structures }(\mathbf{1 \% )}\end{array}$ & \\
\hline
\end{tabular}




\begin{tabular}{|c|c|}
\hline & $\begin{array}{l}\text { Pneumothorax / hemothorax } \\
\text { Intestinal perforation } \\
\text { - Malignant tract seeding (very rare) } \\
\text { - Death (very rare) }\end{array}$ \\
\hline Minor & $\begin{array}{l}\text { Hemorrhage not requiring intervention } \\
\text { Transient pain }\end{array}$ \\
\hline
\end{tabular}


Supplementary Tables: PNB procedural features and complications by anatomical regions

Table 10: MSK

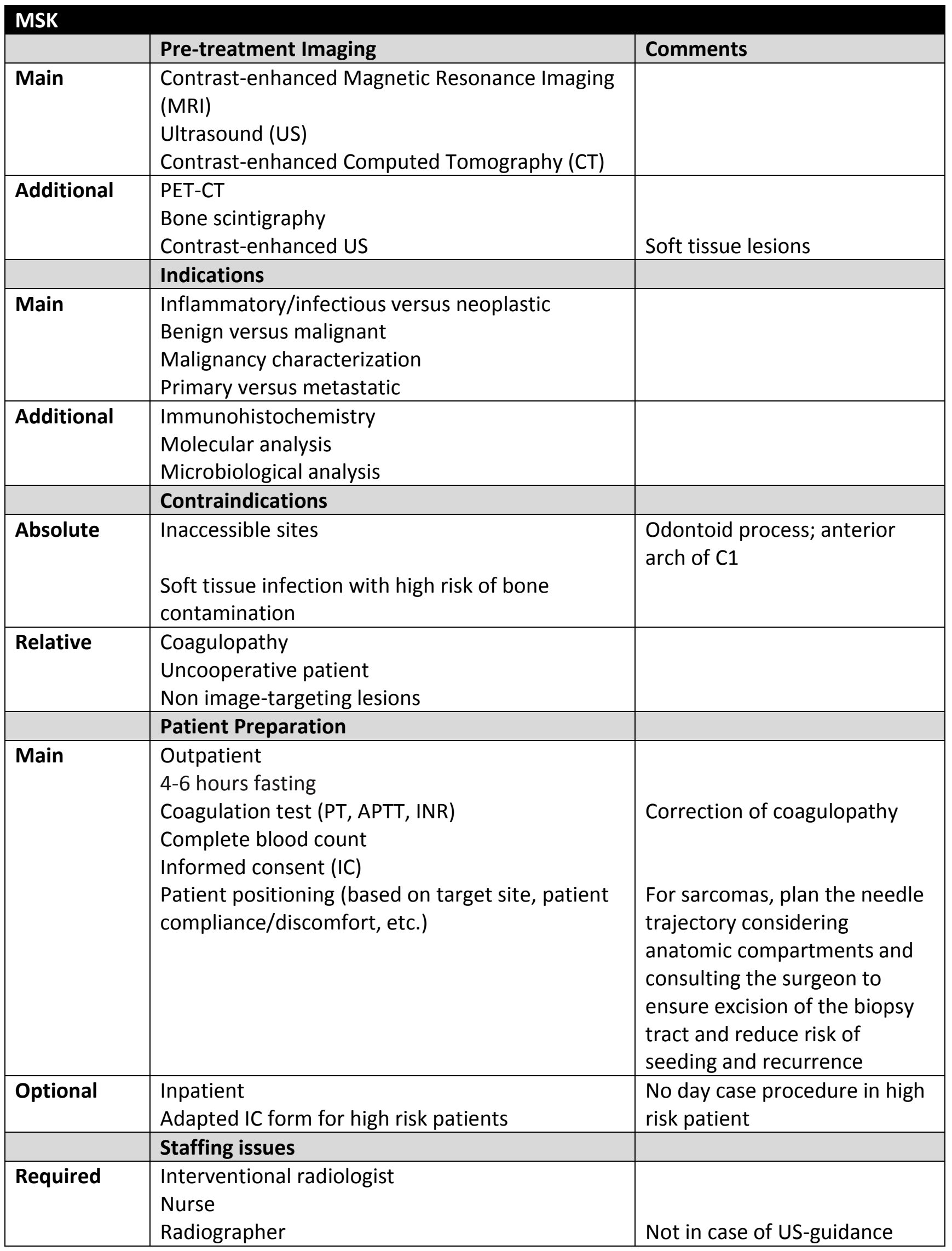




\begin{tabular}{|c|c|c|}
\hline Additional & $\begin{array}{l}\text { Anaesthesiologist for sedation } \\
\text { Pathologist on site }\end{array}$ & \\
\hline & Facility & \\
\hline Required & $\begin{array}{l}\text { Pulse and blood pressure monitoring } \\
\text { Emergency resuscitation equipment }\end{array}$ & \\
\hline \multirow[t]{2}{*}{ Optional } & $\begin{array}{l}\text { Equipment for decompression of tension } \\
\text { pneumothorax (MSK thoracic biopsy) } \\
\text { Facilities for onsite cytopathology assessment }\end{array}$ & \\
\hline & Imaging guidance & \\
\hline Main & $\begin{array}{l}\text { CT } \\
\text { Fluoroscopy } \\
\text { US (including color-Doppler) }\end{array}$ & $\begin{array}{l}\text { US: for superficial lesions with } \\
\text { large soft tissue component } \\
\text { and minimal ossification }\end{array}$ \\
\hline \multirow[t]{2}{*}{ Additional } & $\begin{array}{l}\text { MRI } \\
\text { CT-fluoroscopy } \\
\text { Fusion imaging (US, MRI, PET-CT) } \\
\text { CEUS }\end{array}$ & $\begin{array}{l}\text { Navigation system when } \\
\text { needed and available }\end{array}$ \\
\hline & Technique & \\
\hline Required & $\begin{array}{l}\text { Skin disinfection and local anaesthesia } \\
\text { Coaxial technique } \\
\text { Trephine-type needle for sclerotic lesions } \\
\text { Fine needle aspiration (FNA): } 20-22 \mathrm{G} \\
\text { Core biopsy (CB): } 14-18 \mathrm{G} \\
\text { Samples collection and formalin fixation }\end{array}$ & $\begin{array}{l}\text { FNA: usually adequate for } \\
\text { metastatic lesions and } \\
\text { infection } \\
\text { CB: required for suspected } \\
\text { primary tumours }\end{array}$ \\
\hline \multirow[t]{2}{*}{ Optional } & $\begin{array}{l}\text { Conscious sedation } \\
\text { Neuroleptanalgesia for painful lesions } \\
\text { General anaesthesia for children } \\
\text { Extemporary touch imprints or smears evaluation } \\
\text { In sarcoma, mark biopsy tract and entry site in } \\
\text { indelible ink for subsequent surgical excision } \\
\text { CT (or other imaging modalities) post-procedural } \\
\text { control }\end{array}$ & $\begin{array}{l}\text { Touch imprints or smears } \\
\text { evaluation when pathologists } \\
\text { or cytotechnologists on site }\end{array}$ \\
\hline & Periprocedural Care & \\
\hline Required & $\begin{array}{l}\text { Pulse and blood pressure monitoring } \\
4-6 \text { hours observation after the procedure }\end{array}$ & \\
\hline \multirow[t]{2}{*}{ Additional } & $\begin{array}{l}\mathrm{O}_{2} \text { saturation monitoring } \\
\text { Pain control }\end{array}$ & $\begin{array}{l}\text { Management of complications, } \\
\text { if any }\end{array}$ \\
\hline & Effectiveness & \\
\hline Technical & $\begin{array}{l}\text { Adequacy of sample }>90 \% \\
\text { Diagnostic accuracy: } 74-97 \% \\
\end{array}$ & $\begin{array}{l}\text { Recommended quality } \\
\text { improvement threshold: } 70 \%\end{array}$ \\
\hline \multirow[t]{2}{*}{ Clinical } & Biopsy outcome relevant for management & Monitored by periodic audit \\
\hline & Complications & \\
\hline Major & $\begin{array}{l}\text { Haemorrhage requiring transfusion or other } \\
\text { intervention (rare) } \\
\text { Infection }(<1 \%)\end{array}$ & \\
\hline
\end{tabular}




\begin{tabular}{|c|c|}
\hline & $\begin{array}{l}\text { Neurologic injury } \\
\text { Pneumothorax/hemothorax requiring chest tube } \\
\text { placement }(<1 \%) \\
\text { Bone fracture } \\
\text { Needle tip breakage } \\
\text { Tract seeding } \\
\text { Death }\end{array}$ \\
\hline Minor & $\begin{array}{l}\text { Hematoma not requiring intervention } \\
\text { Pneumothorax } \\
\text { Pain }\end{array}$ \\
\hline
\end{tabular}

